Chapter 5

\title{
In situ U-Pb Dating Combined with SEM Imaging on Zircon - An Analytical Bond for Effective Geological Recontructions
}

\author{
Annamaria Fornelli, Giuseppe Piccarreta and \\ Francesca Micheletti \\ Additional information is available at the end of the chapter \\ http://dx.doi.org/10.5772/58540
}

\section{Introduction}

In situ U-Pb dating combined with SEM images on zircon crystals represent a powerful tool to reconstruct metamorphic and magmatic evolution of basements recording a long and complex geological history [1-3].

The development of high spatial and mass resolution microprobes (e.g., LA-ICP-MS, SIMS, SHRIMP) allows in-situ measurements of $\mathrm{U}-\mathrm{Pb}$ ages in micro domains smaller than 30-50 microns $[4,5]$.

The growth of zircon crystals, evidenced by their internal microtextures, can be easily revealed by SEM imaging by Cathodoluminescence (CL) and Variable Pressure Secondary Electrons (VPSE) detectors on separated grains or in situ within a polished thin rock section [6,4,7].

Therefore it is possible to date different domains of single crystals, which may record magmatic or metamorphic events of the rock's geological history [8,4]. In acidic magmatic rocks abundant zircon crystals provide precise age data about magma emplacement and origin of source indicating the geodynamic context and the pertinence of terranes forming the continental crust.

As regards the metamorphic context, zircon can potentially preserves multiple stages of metamorphic records owing its highly refractory nature, high closure temperature and slow diffusion rate of $\mathrm{Pb}$, thus it is an ideal mineral for $\mathrm{U}-\mathrm{Pb}$ dating of poly-metamorphic rocks $[9,10]$. In addition, in situ analyses of trace elements such as rare earth elements (REE) in zircon and between zircon and coexisting minerals is usefull to decipher the REE behavior and 
mineral chemistry during metamorphism and to determine metamorphic P-T conditions $[8,11,12]$. In particular, garnet is one of the most important rock-forming minerals in high-grade metamorphic rocks since it can be also used to constrain metamorphic conditions if its composition is combined with that of other major minerals such as pyroxene and amphibole $[13,14]$. Relatively to REE partition in metamorphic rocks garnet, pyroxene, amphibole and zircon being competitors for REE partition, represent a usefull tool to outline continental crust evolution.

In this paper we present the geochronological and chemistry data collected in the last ten years in Calabria and Peloritani sectors of Italy, utilizing the new analytical techniques, usefull to reconstruct the magmatic and metamorphic history of a key sector of the South European Variscan Belt in the peri-Mediterranean area.

Metaigneous and metasedimentary rocks of the Calabria-Peloritani Terrane (Southern Italy) represent a particularity in the South Mediterranean area being connected to Alpine chain (Norther Italy) through sedimentary Apennines Chain. They rapresent sectors of Variscan upper, intermediate and lower continental crust sutured by a thick layer of CarboniferousPermian granitoids overlapped on Alpine oceanic crust units. Only rocks forming intermediate and deep crust levels of the continental crust were considered in this review. These rock types preserve memory of Precambrian to Permian geological events and in some cases up to Mesozoic times. The available geochronological data [15-24] togheter with CL and VPSE imaging and the REE-U-Th distribution in the zircon domains helped to depict the geological history through: (1) the emplacement ages of the protoliths of metaigneous rocks, (2) the contribution of the Neoproterozoic-Early Cambrian anatectic melts to produce the protoliths of Variscan metaigneous rocks, (3) the sedimentation ages of the protoliths of the metasedimentary rocks; (5) the P-T-t path of the Variscan metamorphism. In the following, an extensive and detailed description of utilized analytical techniques was presented together with the realized geological deductions relatively to Calabria-Peloritani Terrane.

\section{Analytical techniques}

\subsection{Sample preparation}

The U-Pb age data were obtained on zircons directly separated from samples or on polished thin rock sections. In the last case, in situ analyses allow to evaluate the micro-domains in which the zircon grew or was resetted. Separated zircon crystals were selected from 50-125 $\mu \mathrm{m}$ and 125-250 $\mu \mathrm{m}$ fractions extracted from about 5-10 kg of each rock sample. Crushing, heavy liquids, a Carpco and a Frantz magnetic separators have been used for mineral separation. The clearest, crack-and inclusion-free zircon grains were handpicked under binocular microscope and finally mounted in epoxy resin (Fig.1).

Only in the case of SIMS analyses, selected crystals were mounted together with chips of zircon standards (Fig.1), whereas for LA-ICP-MS analyses external standards were used. Grains were 


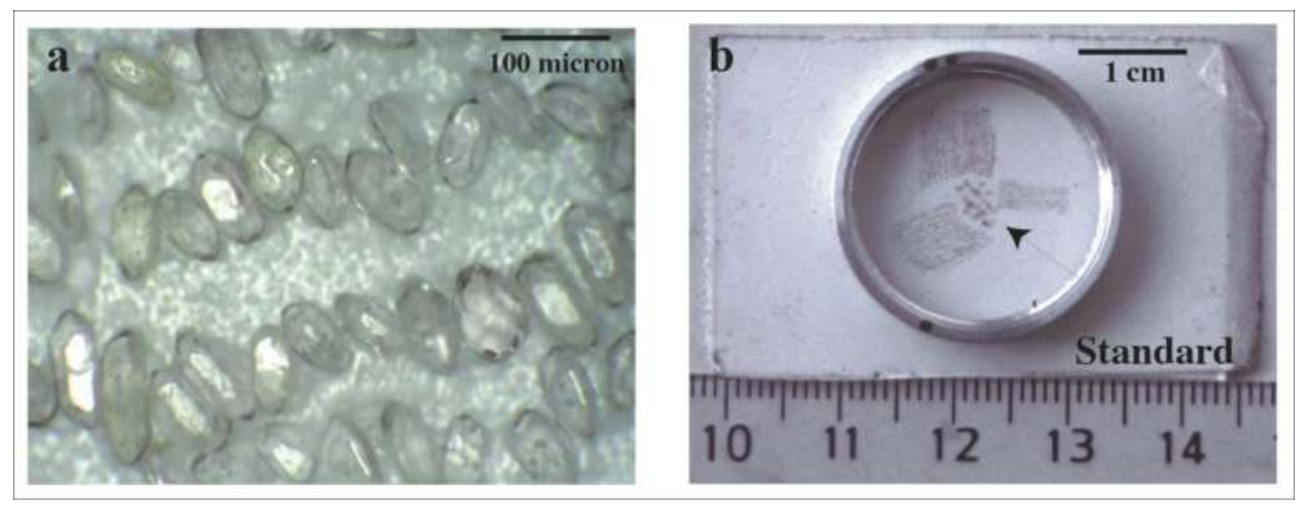

Figure 1. Zircon crystals separated from a rock sample (a) and placed in a mount with standard crystals (b).

then polished to half their thickness to expose internal structures. In the case of selected zircons in thin section, they are chosen also for their peculiar structural site.

\subsection{Zircon imaging}

All crystals were inspected under transmitted light and by SEM (Scanning Electron Microscope) in order to investigate their morphology and collect high-resolution images unravelling the internal microstructures. The first observations on zircon crystals were realized by BSED (Back-Scattered Electron Detector), in order to examine morphologic characters and the possible presence of inclusions of other minerals.

The high-resolution images of internal zoning patterns of zircons were realized by CL (Cathodoluminescence) and by VPSE (Variable Pressure Secondary Electrons) detectors, the last used in high vacuum conditions. Operating conditions were an accelerating voltage of $15 \mathrm{kV}$ with a beam current of $20 \mathrm{nA}$ for CL images and $100 \mathrm{nA}$ for VPSE images. The images obtained by two different detectors (CL and VPSE, Fig.2) are almost completely overlapping $[25,26]$.

The most suitable location of the spots for $\mathrm{U}-\mathrm{Pb}$ analyses was then selected. Zircon grains were also inspected after the isotopic and chemical analyses in order to define the precise spot location with respect to internal microstructures (Fig.3).

\subsection{In situ $\mathrm{U}-\mathrm{Pb}$ data acquisition on zircon crystals}

$\mathrm{U}-\mathrm{Pb}$ age data on zircons were performed by LA-ICP-MS, SIMS and SHRIMP techniques. Three techniques produce comparable results with equally accurate $\mathrm{U}-\mathrm{Pb}$ zircon ages $[5,27,17]$. However, LA-ICP-MS technique is generally preferred for the greater simplicity of use, the faster data capture (ca 4 minutes per analysis versus ca 30 minutes per SIMS and SHRIMP analysis; see [5]) and because it allows a complete acquisition of trace element composition in selected zircon domains. 

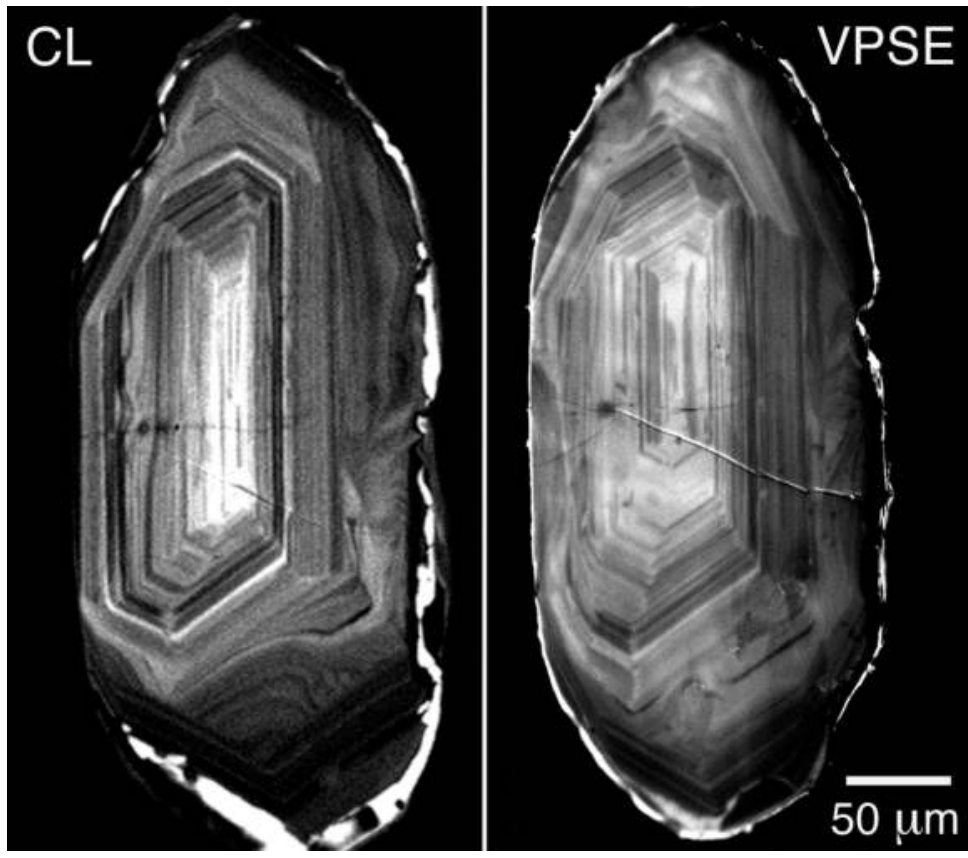

Figure 2. The same zircon crystal investigated by Cathodoluminescence Detector (CLD) and Variable Pressure Secondary Electrons Detector (VPSED). With the permission of Acquafredda and Fiore (2005).

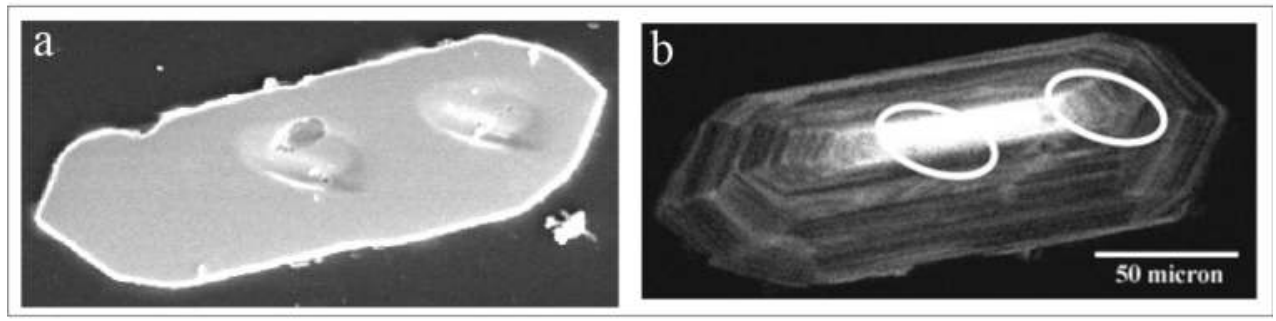

Figure 3. Images of the same zircon crystal obtained by BSE (a) and VPSE detectors (b). In (a) the craters left by microprobe are clearly visible.

\subsubsection{LA-ICP-MS (Laser Ablation-Inductively Coupled Plasma-Mass Spectrometry)}

LA-ICP-MS U-Pb data on zircons $(17,18,7,22,21,20,24)$ were performed at the CNR-Istituto di Geoscienze e Georisorse (Pavia, Italy) using a $193 \mathrm{~nm}$ ArF excimer laser ablation microprobe (Geo-Las200Q-Microlas) coupled to a magnetic sector high resolution-ICP-MS (Element I from Thermo Finnigan). 
The analyses were carried out in single spot mode and with a spot size of approximately $20 \mu \mathrm{m}$. The laser was operated with $5 \mathrm{~Hz}$ of frequency and 12J $\mathrm{cm}^{-2}$ of fluence. Sixty seconds of background signal and at least $30 \mathrm{~s}$ of ablation signal were acquired. The signals of masses ${ }^{202} \mathrm{Hg},{ }^{204}(\mathrm{~Pb}+\mathrm{Hg}),{ }^{206} \mathrm{~Pb},{ }^{207} \mathrm{~Pb},{ }^{208} \mathrm{~Pb},{ }^{232} \mathrm{Th}$ and ${ }^{238} \mathrm{U}$ were acquired in magnetic scan mode. ${ }^{235} \mathrm{U}$ is calculated from ${ }^{238} \mathrm{U}$ on the basis of the ratio ${ }^{238} \mathrm{U} /{ }^{235} \mathrm{U}=137.88$. The 202 and 204 masses were collected in order to monitor the presence of common $\mathrm{Pb}$ in zircon. In particular, the signal of ${ }^{202} \mathrm{Hg}$ was acquired to correct the isobaric interference of ${ }^{204} \mathrm{Hg}$ on ${ }^{204} \mathrm{~Pb}$ [28]. The relatively high $\mathrm{Hg}$ background, however, hampers the detection of low ${ }^{204} \mathrm{~Pb}$ signals and, as a consequence, also the calculation of small common $\mathrm{Pb}$ contribution. Generally, the analysed zircons showed signals of 204 mass elements, which were indistinguishable from the background; thus no common $\mathrm{Pb}$ correction was applied (more analytical details in [29]).

All fractionation effects involving $\mathrm{Pb} / \mathrm{U}$ ratios (e.g. mass bias and laser induced fractionation) were corrected by using the external zircon standard 91,500 (1,065 Ma [30]). The same spot size and integration intervals were considered on both standard and studied zircons. During each analytical run reference zircon 02123 (295 Ma [31]) was analysed together with unknowns for quality control. Data reduction was carried out through the GLITTER software package [32]. Time resolved signals were carefully inspected to detect perturbation of the signal related to cracks or mixed age domains that were avoided in the integration intervals.

Within the same analytical run, the uncertainty associated to the reproducibility of the external standards was propagated to each analysis (see Horstwood et al. 2003) and after this procedure each age determination is considered as accurate within a quoted uncertainty.

Correlation coefficients for the ${ }^{206} \mathrm{~Pb} /{ }^{238} \mathrm{U}$ and ${ }^{207} \mathrm{~Pb} / 235 \mathrm{U}$ data point uncertainties are calculated simply as a ratio of the two uncertainties [33].

LA-ICP-MS technique also permits a complete acquisition of trace element composition in specific zircon domains. In this case a dedicated configuration of the machine couples a Nd: YAG laser working at $266 \mathrm{~nm}$ with a quadrupole ICP mass spectrometer type DRCe from Perkin Elmer.

For trace element determination the laser was operated at a repetition rate of $10 \mathrm{~Hz}$, with pulse energy of about $0.01 \mathrm{~mJ}$ and an ablation spot of about $25 \mu \mathrm{m}$ in size. NBS NIST-610 and $\mathrm{SiO}_{2}$ were adopted as external and internal standard, respectively. Data reduction was carried out through the GLITTER software package [32].

Minimum detection limits at $99 \%$ confidence level were $<10-5$ ppm for the most of the elements. Precision and accuracy were assessed on the BCR-2 USGS reference glass and are more than $6 \%$ relative.

\subsubsection{SIMS (Secondary Ion Mass Spectrometry)}

SIMS data [16,17] were collected using the Cameca IMS-1270 ion microprobe (CRPGCNRS, Nancy, France). Primary O2- ion beam was accelerated at $13 \mathrm{kV}$ with an intensity that ranged between 5 and $20 \mathrm{nA}$ and focused on a 20-25 $\mu \mathrm{m}$ diameter area, providing 
a mean secondary ions yield of $25 \mathrm{cps} / \mathrm{nA} / \mathrm{ppm}$. Each spot was analysed for $18 \mathrm{~min}$, after a presputerring of $2 \mathrm{~min}$. An empirical relationship between $\mathrm{UO}+/ \mathrm{U}+$ and $\mathrm{Pb}+/ \mathrm{U}+$ was defined from all the measurements performed on the standard parts of each sample mount in order to determine the relative sensitivity factor for $\mathrm{Pb}$ and $\mathrm{U}$ used for samples [34]. Also in this case zircon 91,500 (1,065 Ma, [30]) is the reference standard. Correction for common lead was made measuring the $204 \mathrm{~Pb}$ amount. The common lead composition was calculated at ${ }^{207} \mathrm{~Pb} /{ }^{206} \mathrm{~Pb}$ measured ages, using Stacey and Kramers model [35]. The ${ }^{206} \mathrm{~Pb} /{ }^{204} \mathrm{~Pb}$ ratios range in most case from 3,000 to more than 50,000 , and thus the common $\mathrm{Pb}$ composition chosen for correction is not highly critical. Further information on instrumental conditions and data reduction procedures are found in [36]. Errors include the analytical statistical error, the error associated with the common lead correction and the systematic error associated with the $\mathrm{U} / \mathrm{Pb}$ calibration procedure [36]. As regards the ion microprobe analyses we used ${ }^{206} \mathrm{~Pb} / 238 \mathrm{U}$ ages for all the data instead of ${ }^{207} \mathrm{~Pb} /{ }^{235} \mathrm{U}$ ages, which are more sensitive to common lead contribution, being the ${ }^{207} \mathrm{~Pb}$ ion signal about ten times lower than the ${ }^{206} \mathrm{~Pb}$ ion signal [36].

\subsubsection{SHRIMP (Sensitive High Resolution Ion MicroProbe)}

SHRIMP data were collected [19,23] using procedures based on those described by [37]. A 2.5 $\mathrm{nA}, 10 \mathrm{kV}$ primary beam of O2-ions was focused to a probe of c. $25 \mu \mathrm{m}$ diameter. Positive secondary ions were extracted from the sample at $10 \mathrm{kV}$, and the atomic and molecular species of interest analysed at c. 5000 mass resolution using a single ETP electron multiplier and peak switching. The Pb isotopic composition was measured directly, without correction for the small mass dependent mass-fractionation (c. $0.25 \%$ per a.m.u.). Interelement fractionation was corrected using the TEMORA II reference zircon, using a $\mathrm{Pb} / \mathrm{U}-\mathrm{UO} / \mathrm{U}$ power law calibration equation [38]. The uncertainty in the $\mathrm{Pb} / \mathrm{U}$ calibration was $0,46 \% . \mathrm{Pb}, \mathrm{U}$ and Th concentrations were measured relative to SL13 reference zircon. Common Pb corrections were very small (most $<0.3 \mathrm{ppm}$ total $\mathrm{Pb}$ ), so all were made assuming that the common $\mathrm{Pb}$ was all laboratory contamination of Broken Hill galena $\mathrm{Pb}$ composition $\left({ }^{204} \mathrm{~Pb} /{ }^{206} \mathrm{~Pb}=0.0625,{ }^{207} \mathrm{~Pb} /{ }^{206} \mathrm{~Pb}=0.962\right.$, ${ }^{208} \mathrm{~Pb} /{ }^{206} \mathrm{~Pb}=2.23$; [39]). Corrections for the plots and isotopic data table were made using ${ }^{204} \mathrm{~Pb}$. Corrections for the calculation of mean ${ }^{206} \mathrm{~Pb} /{ }^{238} \mathrm{U}$ ages used ${ }^{207} \mathrm{~Pb}$, assuming the analyses to be concordant. Ages were calculated using the constants recommended by the IUGS Subcommission on Geochronology [40].

All collected data were traited by the software package Isoplot/Ex3.00 [41]. This software was used for the concordia test and the probability of concordance calculation, performed for each analytical spot from ${ }^{206} \mathrm{~Pb} / 238 \mathrm{U}$ and ${ }^{207} \mathrm{~Pb} / 235 \mathrm{U}$ ratios. The Isoplot/Ex3.00 software was also used to construct Concordia, possible discordia lines and probability density plots and to calculate the mean concordia ages for data clusters defined on the basis of: (i) statistical significance, (ii) the visual appearance on the Concordia plot, (iii) the peak distribution along the probability density plot, and (iv) the correspondence with specific internal microstructures of zircon. 


\section{Geological setting of case study}

The Calabria-Peloritani Terrane (CPT) represents an "exotic terrane" formed by a PreMesozoic basement consisting of different tectonic units affected by Variscan metamorphism and stacked during the Alpine orogenesis [42-43]. It carries the cristalline Massifs of Calabria (Sila, Serre and Aspromonte) and Peloritani Mountains in Sicily (Fig.4).

In the following, we describe the geological and petrological features of the four considered tectonic units representing portions of middle and lower continental crust. Many samples from the different rock types in each unit were considered with the aim to reconstruct and date the geological events recorded by zircon grains. The mineralogical composition of the all cited samples and their relative spectrum of $\mathrm{U}-\mathrm{Pb}$ zircon ages are reported in Table 1 . Their exact localization is indicated in Fig.4.

Four tectonic units were considered along the CPT from North to South (Fig. 4):

The Mandatoriccio Complex outcropping in Sila Massif represents intermediate continental crust and consists mainly of metapelites, meta-arenites, acidic metavolcanites and metabasites with rare intercalations of marbles and orthogneisses crosscutted by abundant aplite and pegmatite veins [44-46]. Metasediments show a static porphyroblastic growth mainly of biotite, garnet, andalusite, staurolite and muscovite [46-48]. Recently, clockwise P-T paths have been constrained for siliciclastic metasediments of this complex. Peak-metamorphic conditions of ca. $590{ }^{\circ} \mathrm{C}$ and $0.35 \mathrm{GPa}$ are reported for the lower structural levels of the Mandatoriccio Complex and they were reached at $299 \mathrm{Ma}$ (U-Th-Pb ages in monazite, [46]) during Variscan post-orogenic extension.

The Castagna Unit outcropping in the central part of Calabria, consists of paragneisses, micaschists, augen gneisses, Variscan granitoids and minor amphibolites, quartzites, calcsilicate rocks and marbles [49,50]. It includes metamorphic rocks equilibrated under greenschist to amphibolite facies conditions in Variscan times and reworked by Alpine tectonics $[49,46,18]$.

The Sila Unit occupies wide areas in Sila and Serre Massifs. In the Serre the section of Variscan crust consists, from the bottom to the top of: i) 7-8 km thick lower crustal rocks, ii) an about $10 \mathrm{~km}$-thick "layer" of granitoids [51] emplaced $300 \mathrm{Ma}$ ago (U-Pb conventional zircon data, [51,52]), and iii) amphibolite to sub-greenschist facies metamorphic rocks of the upper crust. The geochronological features of the lower portion recording Variscan amphibolite-granulite facies metamorphism and representing a fragment of deep crust were considered. This section includes from the bottom: a) felsic and mafic granulites with rare meta-peridotites and metapelites, b) migmatitic metapelites with interleaved metabasites, rare marbles and augen gneisses. The metabasic rocks from the lower part of the section together with the augen gneisses from the upper part of the section bear memory of preVariscan magmatism (Table 1).

The Aspromonte-Peloritani Unit (APU) outcrops in Southern Calabria and Eastern Sicily (Fig. 4); it consists of augen gneisses, micaschists, biotite paragneisses with minor amphib- 
olites and marbles. A pre-Variscan origin of protoliths of augen gneisses at 543-545 Ma was suggested by spot U-Pb zircon ages [16,23,53]. According to [23] the timing of highgrade metamorphism accompanied by partial melting in paragneisses, was sinchronous (at $545 \mathrm{Ma}$ ) with the intrusion of protoliths of augen gneisses. The metamorphic rocks are diffusely intruded by late-Variscan peraluminous granitoids [54-57,19], sometimes affected by Alpine metamorphism. P-T estimates for the Variscan tectono-metamorphic evolution indicate $\mathrm{T}$ around $650-675^{\circ} \mathrm{C}$ and $\mathrm{P}$ of about $0.4-0.5 \mathrm{GPa}[58,59]$. The evolution of the APU provides crustal thickening during early-middle Variscan collisional stages, followed by crustal thinning, granitoid intrusion and unroofing during late-Variscan extensional stages [43].

The collected data in Southern Italy give constraints about the complex magmatic and metamorphic history of South European Variscan Chain in the peri-Mediterranean area. Magmatic and metamorphic events are recorded in the considered rocks from Late-Neoproterozoic-early Cambrian to Permian times. In the following, the geological history is punctually depicted.

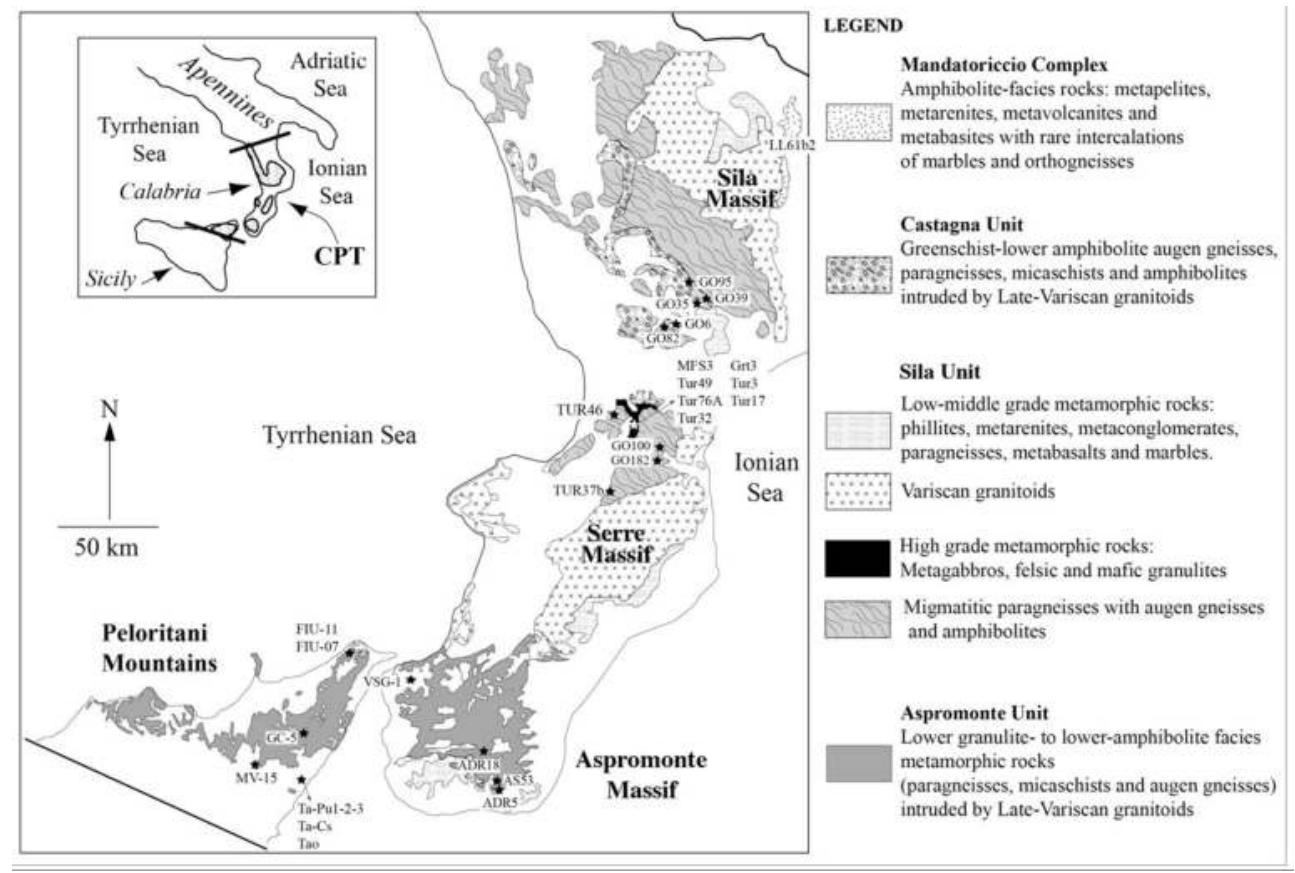

Figure 4. - Geological sketch map of CPT with the indication of considered samples in four different structural units. 


\begin{tabular}{|c|c|c|c|c|c|c|c|c|c|c|c|}
\hline 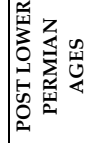 & & 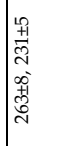 & 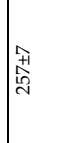 & & $\begin{array}{l}\text { 菬 } \\
\text { d }\end{array}$ & & 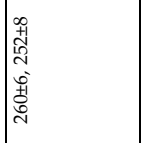 & & & & \\
\hline 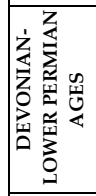 & & 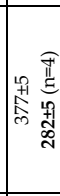 & 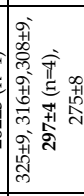 & 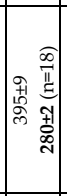 & 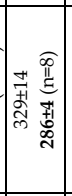 & 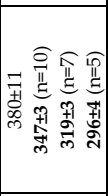 & 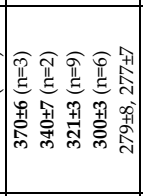 & 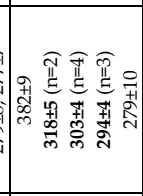 & 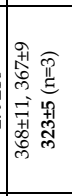 & 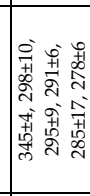 & 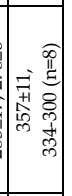 \\
\hline 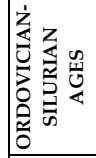 & 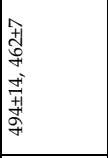 & 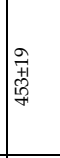 & $\begin{array}{c}\text { के } \\
0 \\
\infty \\
\infty\end{array}$ & & & 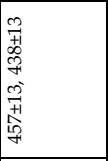 & 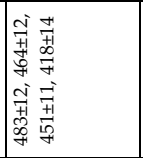 & & & 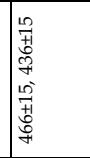 & \\
\hline 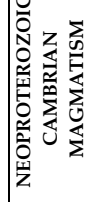 & 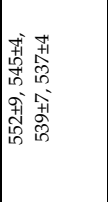 & 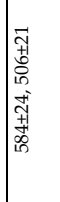 & & & & 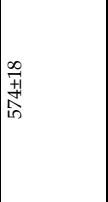 & 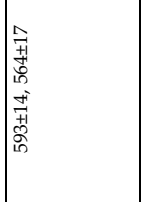 & 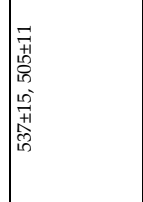 & & & \\
\hline 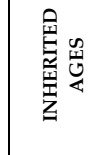 & 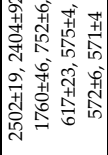 & & 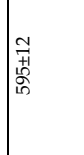 & & & 売 & & 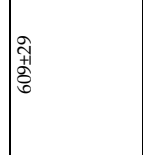 & & & \\
\hline 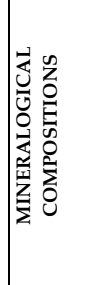 & 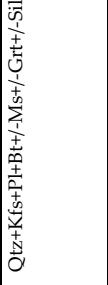 & 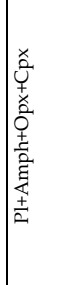 & 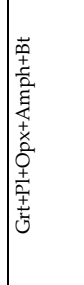 & 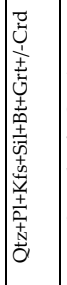 & 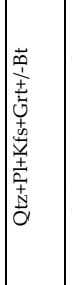 & 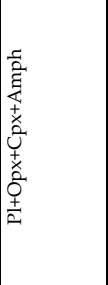 & 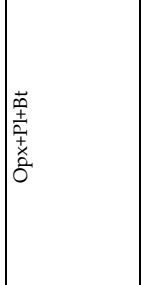 & 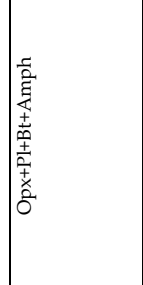 & 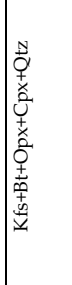 & 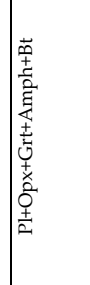 & 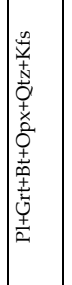 \\
\hline 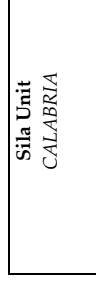 & 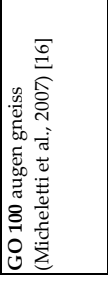 & 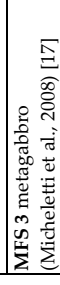 & 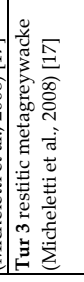 & 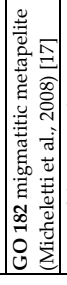 & 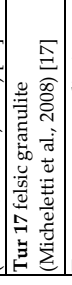 & 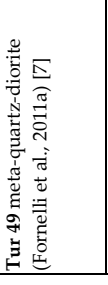 & 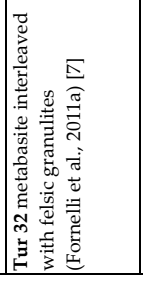 & 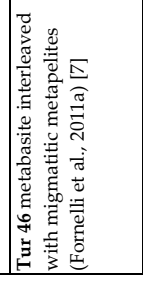 & 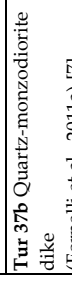 & 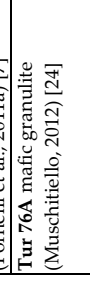 & 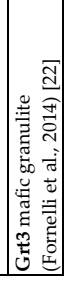 \\
\hline
\end{tabular}




\begin{tabular}{|c|c|c|c|c|c|}
\hline 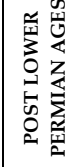 & & & 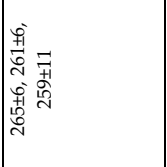 & 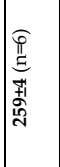 & 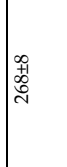 \\
\hline 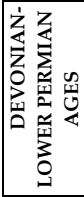 & & & 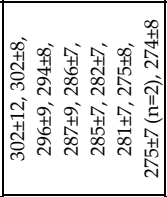 & 秊 & 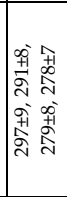 \\
\hline 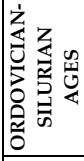 & 贲 & & 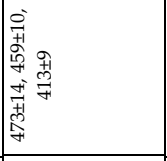 & 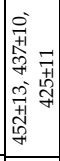 & \\
\hline 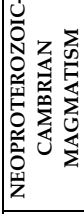 & 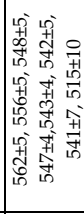 & 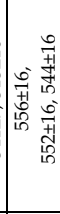 & 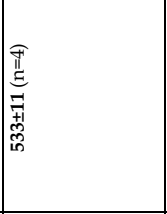 & 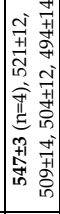 & \\
\hline 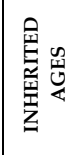 & 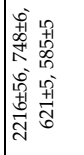 & 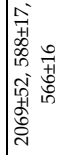 & 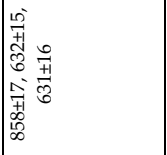 & 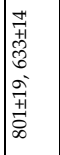 & \\
\hline 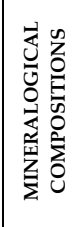 & 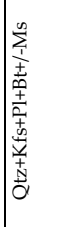 & 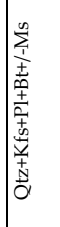 & 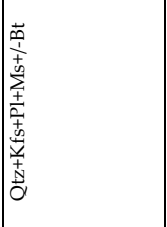 & 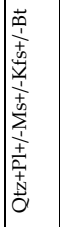 & 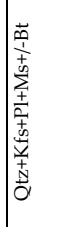 \\
\hline 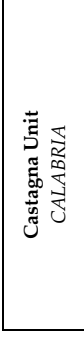 & 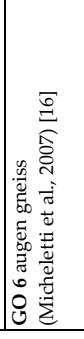 & 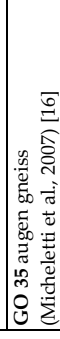 & 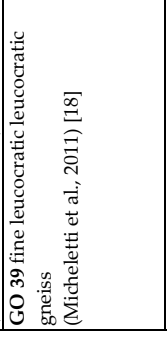 & 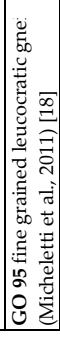 & 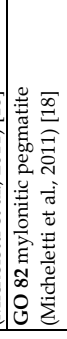 \\
\hline
\end{tabular}

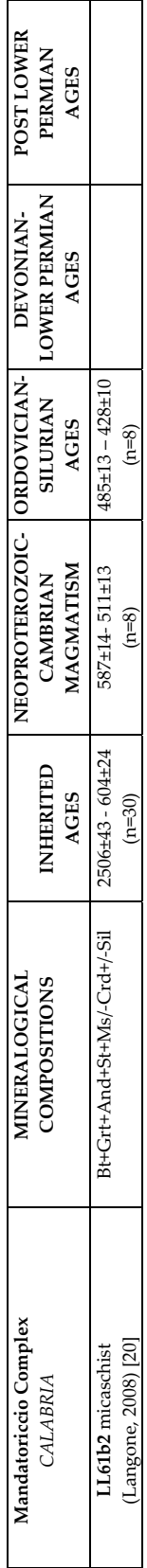




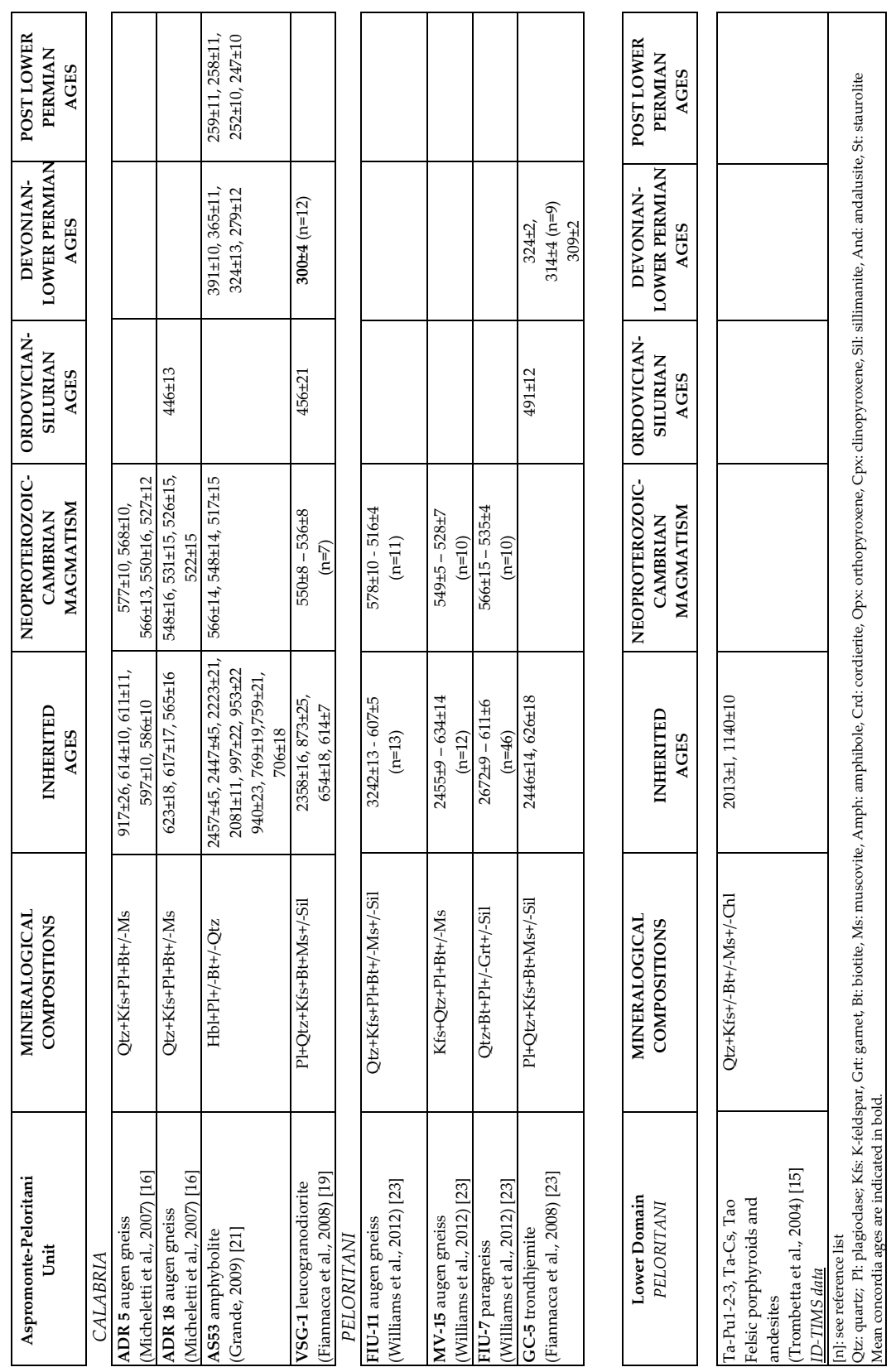

Table 1. U-Pb concordant data on zircon in the studied rocks from CPT continental crust 


\subsection{Geological reconstructions inferred from $\mathrm{U}-\mathrm{Pb}$ spot data}

\subsubsection{Recognizable Gondwana pertinence}

Memory of the magmatic Proterozoic events widely occurs in the rocks of the CalabriaPeloritani Terrane as inherited ages preserved in detrital zircons or xenocrystic cores surrounded by younger overgrowths (Fig. 5).
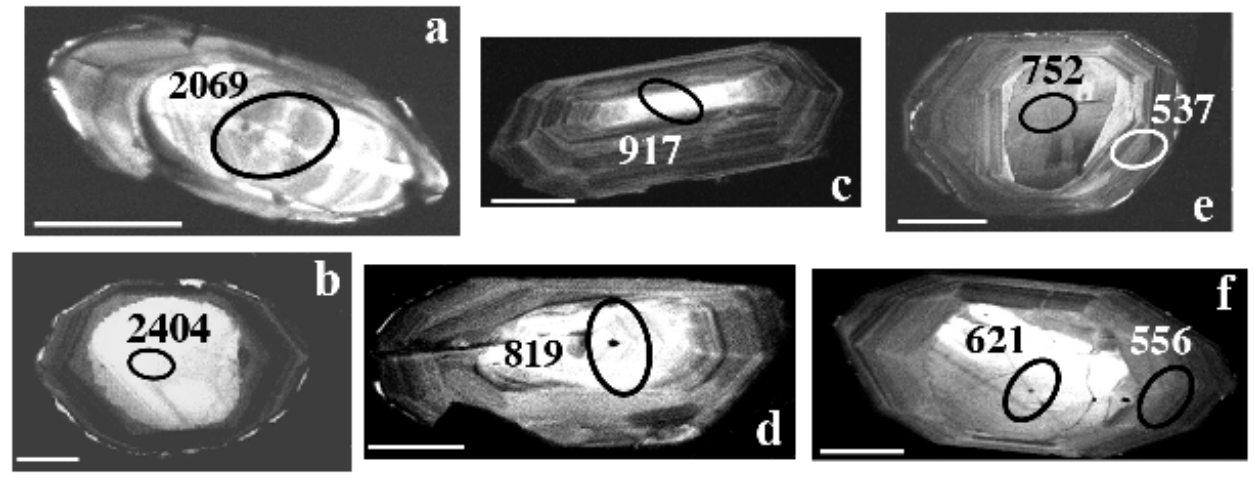

$\overline{\text { Scale bar: } 50 \mu \mathrm{m}}$

Figure 5. CL images of zircons showing detritic characters (a-b-c-d) and xenocrystic cores (e-f). Note the younger overgrowths in e and $f$.

The zircon ages revealed in the different rock-types of the described units are detailed in the following:

- Metagranitoids (augen gneisses) belonging to Aspromonte-Peloritani, Castagna and Sila Units having Fortunian-Ediacaran protoliths (Table 1) preserve inherited zircon ages covering a time span of 2500-1760 Ma and 917-610 Ma [16,18]. In addition, they show Sm$\mathrm{Nd}$ model ages ranging from 1700 to $1500 \mathrm{Ma}$ [16];

- Granulite facies metabasic rocks of the Sila Unit record two Neoproterozoic inherited age (744 $\pm 20 \mathrm{Ma}$ and $609 \pm 29 \mathrm{Ma}$ ) despite their magmatic mantle origin in the NeoproterozoicCambrian times [7];

- Metasediments from the lower and upper crust of the Sila Unit preserve memory of old events at 2500, 2300, 2000 and 1900 Ma obtained as upper intercepts of U-Pb discordia lines (isotopic dilution method in [60,61]). Furthermore they show Nd model ages of $1500 \mathrm{Ma}$ [60] and $1350 \mathrm{Ma}$ [61]; 
- Amphibole bearing-micaschists from Mandatoriccio Unit preserve xenocrystic cores old up to $2562 \pm 44$ Ma [20];

- Amphibole bearing-gneisses from Aspromonte-Peloritani Unit preserve inherited ages from 2500 Ma to $706 \mathrm{Ma}$ [21];

- In Eastern Sicily ortho-and para-gneisses belonging to APU show clusters of Proterozoic ages around 2400-2700 Ma, 900-1100 Ma and 540-850 Ma and some ages at 3200, 1800 and 1600 Ma were also obtained [23].

Still in Eastern Sicily (Lower domain) Ordovician porphyroids preserve inherited ages at $1512 \mathrm{Ma}$ and $1380 \mathrm{Ma}$ (upper intercepts of U-Pb discordia lines; ID-TIMS analyses in [15]). Meta-andesites associated with these porphyroids contain older zircons dated at 2015 and 1150 Ma [15].

The inherited zircon age patterns in Calabria rocks indicate Gondwana domain pertinence. In particular, the similarities in age and chemistry of the protoliths of Calabria augen gneisses with the acidic magmatites from Anti-Atlas Moroccan domain point to a source derived from a reworking of the West African Craton (WAC) [48] showing similarities with other European Cadomian terranes [62-66]. In fact, analogous inherited age patterns occur in other sectors of European Variscides [63]: Southern British Islands, Armorica Massif and Massif Central in France, Bradant Massif (Belgium), Iberian Massif (Spain and Portugal) and Bohemian Massifs (Czech Republic). The distribution of these ages suggests Cadomian pertinence with West African Craton affinity. According to [23], the inherited zircon age patterns in the augen gneisses and paragneisses from Aspromonte-Peloritani Unit in the Sicily bear evidence, on the whole, of East African provenance owing to age cluster in the range 900-1100 Ma reveled in this area. These authors evidence strong similarities between Sicily terranes and those of other areas in the Eastern Mediterranean region as Southern Israel, Jordan and Arabia and suggest an East African provenance as several pieces of basements in Mediterranean area, like Turkey, Greece, Sardinia and Cyclades [23]. Considering the whole set of inherited zircon ages in Calabria and Sicily, we can suggest that a both East and West African provenance was effective in Southern Italy as happened in other Mediterranean areas where pre-Variscan basements, starting with Neoproterozoic, are considered as derived from both East and West Gondwanan cratonic sources $[67,68]$. The presence of detritic components having West and East African origin was reveled by inherited zircon ages acquired with different techniques in many samples from different domains of Calabria and Sicily terrains, revealing the effectiveness of $\mathrm{U}-\mathrm{Pb}$ zircon data.

\subsubsection{Neoproterozoic-Cambrian bimodal magmatism}

In situ U-Pb dating performed in metaigneous rocks on zircon crystals showing euhedral morfology and a typical undisturbed oscillatory zoning [69] (Fig. 6) has evidenced a widespread Neoproterozoic-Cambrian bimodal magmatism in an older basement of CalabriaPeloritani Terrane. Evidences of basic and acidic magmatism are diffused in Calabria from Sila Massif up to Sicily (Fig. 4) in metabasic rocks, augen gneisses, fine-grained leucocratic gneisses and amphibolites (Table 1, [16-18,7,23,21]). 

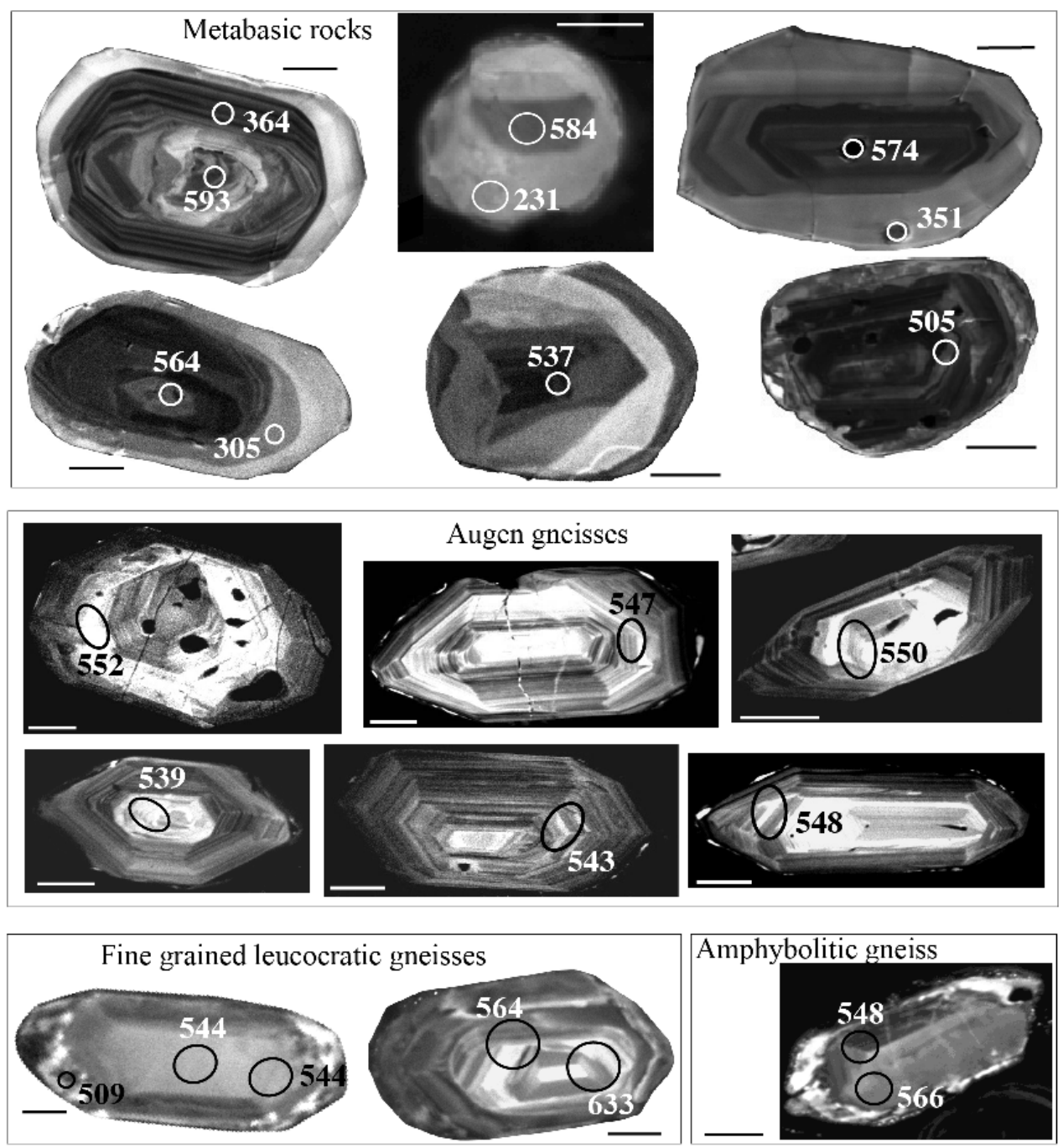

Figure 6. Cathodoluminescence images of zircons in metabasic rocks, augen gneisses, fine grained leucocratic gneisses and amphybolitic gneisses showing characteristic oscillatory zoning interpreted as indicative of their magmatic origin. Scale bar: $50 \mu \mathrm{m}$

Zircons from 2 samples of metagabbro and from 2 samples of metabasites interbedded with felsic granulites and migmatitic metapelites of the lower crust of the Serre Massif belonging to Sila Unit were dated [17,7]. In all samples domains dated 564-593 Ma $(n=4)$ showing magmatic oscillatory zoning and high Th/U ratio (0.16-0.19) are present (Fig. 6). These domains 
show fractionated REE patterns interpreted as formed in absence of garnet considered as Variscan metamorphic phase $[7,70]$. On this basis a magmatic origin of the zircons indicating the age of protoliths in the time range 564-593 Ma was suggested [17,7]. So, a basic magmatism in Calabria occurred in Neoproterozoic times in an older basement, as happened in many of the so-called "Cadomian blocks" widespread from Western Alps to Turkey [71].

This basic magmatism records tholeiitic and calc-alkaline affinities and, due to the association with a thick pile of metasediments, seems to be connected with a (mature?) magmatic arc in orogenic context [72].

Zircon grains from seven samples of biotitic augen gneisses and two samples of fine-grained leucocratic gneisses coming from the Aspromonte-Peloritani (4 samples), Sila (1 sample) and Castagna (4 samples) Units in Calabria [16,18] and Eastern Sicily [23] are considered. These gneisses are intimately associated with metasediments affected by Variscan metamorphism, but their zircon domains do not bear memory of this event, preserving only Pre-Cambrian/ Silurian ages $[16,18,23]$. Only one sample (GO39, Table 1) preserves Devonian-Lower Permian ages interpreted as resetted ages due to thermal input of fluids relased by Late-Variscan plutonites [18].

In the Calabria augen and fine grained leucocratic gneisses, the majority of the concordant ages forms a statistically significant cluster averaging at 543 Ma ( $n=20$ ages from 562 to 532 Ma) mainly related to euhedral crystals without discontinuity between core and rim having $\mathrm{U}$ contents ranging from 659 to $241 \mathrm{ppm}$ and Th/U ratios mostly comprised between 0.2 and 0.5 ; one domain analysed for REEs produces a highly fractionated pattern and a distinct negative Eu anomaly [18] interpreted as primary magmatic characters according to [73] or as recrystallized domains with memory of primary magmatic zircons [74]. The moderate variability and the high values of $\mathrm{Th} / \mathrm{U}$ ratios seem to be more compatible with precipitation from a hybrid magma precursor of the augen gneisses [75] having mantle and crustal origin. Discordia lines with lower intercepts comprised between 562 Ma and 526 Ma have been also calculated considering the discordant data [16].

The augen gneisses from Peloritani Mountains contain zircon grains giving ages around 545 Ma including two kinds of zircon domains having $\mathrm{U}$ contents of 320-940 ppm (Th/U=0.08-0.23) and 40-470 ppm $(\mathrm{Th} / \mathrm{U}=0.12-2.32)$ interpreted as suggestive of magmatic and detritic origin, respectively [23]. On this basis [23] suggest that the protoliths of augen gneisses were the hosting metasediments in which similar ages were detected.

This acidic magmatic activity dated around 543-545 Ma seems to be diffused in the CalabriaPeloritani basement successively than basic magmatism described above.

Chemistry of the augen gneiss indicates that their protoliths derived from shoshonitic to highK calc-alkaline granitoids related to a post-collisional stage [16, 76], probably at the transition from compressional to extensional tectonics or even after the tectonic collapse of an intracontinental orogen [75]. The emplacement age obtained from the protoliths of all granitic gneisses in CPT and their geochemical affinity share similarities with the granitoids widespread at the Northern edge of the West African Craton, especially in Morocco [77-79], Algerian Tuareg Shield [80] and Mauritania [81]. In fact, voluminous high-K calc-alkaline plutonism charac- 

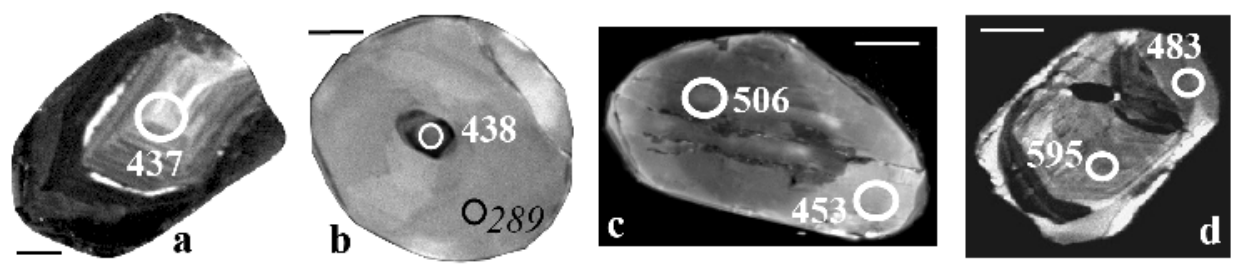

Figure 7. $C L$ and VPSE images of selected zircons showing Ordovician-Silurian ages in fine grained leucocratic gneisses (a), metagabbros (b, c) and restitic metagreywake (d). Scale bar: $50 \mu \mathrm{m}$.

terize the final stages of Panafrican orogeny in Northern margin of the West African Craton as well as in almost all the Cadomian Units along the present Alpine-Mediterranean mountain belts [81,82]. In the period 605-530 Ma, acidic magmatism was diffused at the transition from an active (compressive-transtensive) to a passive (extensional) continental margin with extension and development of foreland basins [83].

It is noteworthy that acidic and basic magmatism of Neoproterozoic-Lower Cambrian times, in Calabria-Peloritani Terrane, is diachronous being mafic magmatic activity 20-40 Ma older than the acidic one [16-18,7]; both magmatic activity monitored the tectonic evolution of Panafrican orogen from compressional to collapse stages [72].

\subsubsection{Ordovician-Silurian tectono-thermal activity}

Ordovician-Silurian ages (data ranging from $494 \pm 14$ to $413 \pm 9 \mathrm{Ma}$ ) have been recorded in augen gneisses, fine-grained leucocratic gneisses and granulite-facies metabasites from Calabria (Table 1) [16-18, 7, 24]. In these rock-types the Ordovician-Silurian ages represent clusters connected to a recrystallization event being the protoliths Neoproterozoic-Cambrian in origin. These ages were measured on cores displaying irregular and patchy microstructures sometimes strongly luminescent (Fig. 7 a-b) or on overgrowths surrounding older cores (Fig. 7 c-d). Owing to the textural features of zircons, the Ordovician-Silurian ages seem related to a tectonothermal event as an effect of recrystallization (see $[84,85])$ producing an isotope resetting at that time.

One sample of augen gneiss (sample GO100, Table 1) from Sila Unit interleaved with the migmatitic metapelites shows two Ordovician ages at $494 \pm 14 \mathrm{Ma}$ and $462 \pm 7 \mathrm{Ma}$ as a $\mathrm{Rb}-\mathrm{Sr}$ isochron at $450 \pm 20 \mathrm{Ma}$ determined in migmatitic metapelites [86]. In addition OrdovicianSilurian detritic population of zircon occurs in the Mandatoriccio micaschists in Mandatoriccio Complex (sample LL61b2, Table 1). In Peloritani Mountains an intermediate-acidic magmatism in Ordovician times was revealed by [15] analysing zircons with magmatic textures from porphyroids and meta-andesites dated at ca. 456-452 Ma.

A look at the European Variscan Chains in which Ordovician-Silurian ages have been detected reveals that from Iberian Massifs to Carpathians several acidic and mafic products are related to a diffusely Ordovician magmatic activity [68]. According to $[67,68,71]$ rifting phases in the Early and Middle Palaeozoic prepared the opening of basins separating the future Variscan 
basement from Gondwana. If a tectono-metamorphic phase was responsible of magmatic activity in Ordovician-Silurian times recorded in Variscan fragments of European Chain, then also the $\mathrm{U}-\mathrm{Pb}$ zircon ages determined in Calabria-Peloritani rocks can be referred to the same phase. Nevertheless, it cannot be excluded that these ages might result from rejuvenation due to the opening of $\mathrm{U}-\mathrm{Pb}$ radiogenic system with partial loss of $\mathrm{Pb}$ during the Variscan metamorphism [16,18]. Alternatively, according to the model proposed by [87], these ages can be related to an Eo-Variscan activity started in Silurian-Ordovician times.

\subsubsection{Variscan orogenesis (Devonian-Lower Permian times)}

The investigated basement forming continental crust units of Calabria and Sicily was affected by Variscan metamorphism and magmatism $[88,42]$ as shown by $\mathrm{Rb}-\mathrm{Sr}$ and $\mathrm{Sm}-\mathrm{Nd}$ isotopic geocronology $[89,61]$. U-Pb zircon age data can be utilized to evidence these geological processes realized under high temperature conditions; in fact zircon has very high closure temperature for $\mathrm{U}-\mathrm{Th}-\mathrm{Pb}$ isotopic system $\left(>900^{\circ} \mathrm{C}\right.$ in [90-92]) then only high-T metamorphic and magmatic conditions can be monitored through $\mathrm{U}-\mathrm{Pb}$ zircon data. Zircons of amphibolitic facies paragneisses and micaschists from Mandatoriccio Complex in Calabria [20] and from Aspromonte-Peloritani Unit in Sicily [23], respectively, do not evidence Variscan ages owing to their low temperature metamorphic conditions (around $500-650^{\circ} \mathrm{C}$; $[20,93]$ ). Zircon is unefficient in these rock types to record geological events under low temperature conditions. This fact is confirmed in the augen gneisses from Castagna and Aspromonte-Peloritani Units (low-medium grade Variscan metamorphism) where ages younger than $413 \mathrm{Ma}$ in Calabria [16] and $\sim 516 \mathrm{Ma}$ in the Sicily [23] were not detected.

Mafic and felsic granulites together with migmatitic metapelites from Sila Unit in Calabria show many U-Pb zircon ages ranging from $\sim 380 \mathrm{Ma}$ to $280 \mathrm{Ma}[17,7]$ testifing the strong efficiency of high grade metamorphism in Variscan times that, in part, masks the original Neoproterozoic-Cambrian ages.

Zircons from these rock types record domains with oscillatory zoning generated by dissolution/re-precipitation or crystallization in presence of melts $[85,94]$ together with lobate structurless grey or luminescent rims invading older cores (metamorphic re-crystallization in [6]) (Fig. 8). The evaluation of zircon textural features on which spot ages were determined constrains step by step the Variscan metamorphic trajectory of the lower crust of the Sila Unit.

Distinct U-Pb zircon age clusters were determined (Table 1): i) a few ages from 380 Ma to 347 Ma; ii) 13 data points around 347-340 Ma; iii) 23 zircon ages clustering at $320 \mathrm{Ma}$; iv) 31 ages around $300 \mathrm{Ma}$; v) several ages in the range 270-280 Ma.

Considering the P-T evolution of the lower crust of the Sila Unit representing a fragment of Variscan continental crust, the revealed cluster ages were interpreted in the following [95]:

a. The ages from $380 \mathrm{Ma}$ to $347 \mathrm{Ma}$ indicate phases of crustal thickening during the prograde metamorphism from amphibolite to granulite facies;

b. The cluster at $347 \mathrm{Ma}$ represents the metamorphic peak at $\mathrm{T}=880^{\circ} \mathrm{C}$ and $\mathrm{P}=1.1 \mathrm{GPa}$ under granulite facies conditions in the lower part of the continental crust section; 
c. The age peaks at 320, 300 and $280 \mathrm{Ma}$ (Table 1; Fig. 8) date the decompression phases. In particular, the cluster at $320 \mathrm{Ma}$ in the granulites coincide with the age of basic Variscan magmatism determined on zircons of a quartz-monzodioritic dike dated at $323 \mathrm{Ma}$ (sample Tur37b, Table 1, Fig.9a). The first decompression stage was accompanied by partial melting in the hosted rocks as shown by zircon domains with oscillatory zoning crystallized by partial melt (Fig. 8). The age peak at about 300 Ma dates a further decompression phase and probably the end of anatexis in the granulites as testified by successive homogeneous and luminescente rims of zircons with ages around $280 \mathrm{Ma}$ in which the Variscan cycle stoped [7].

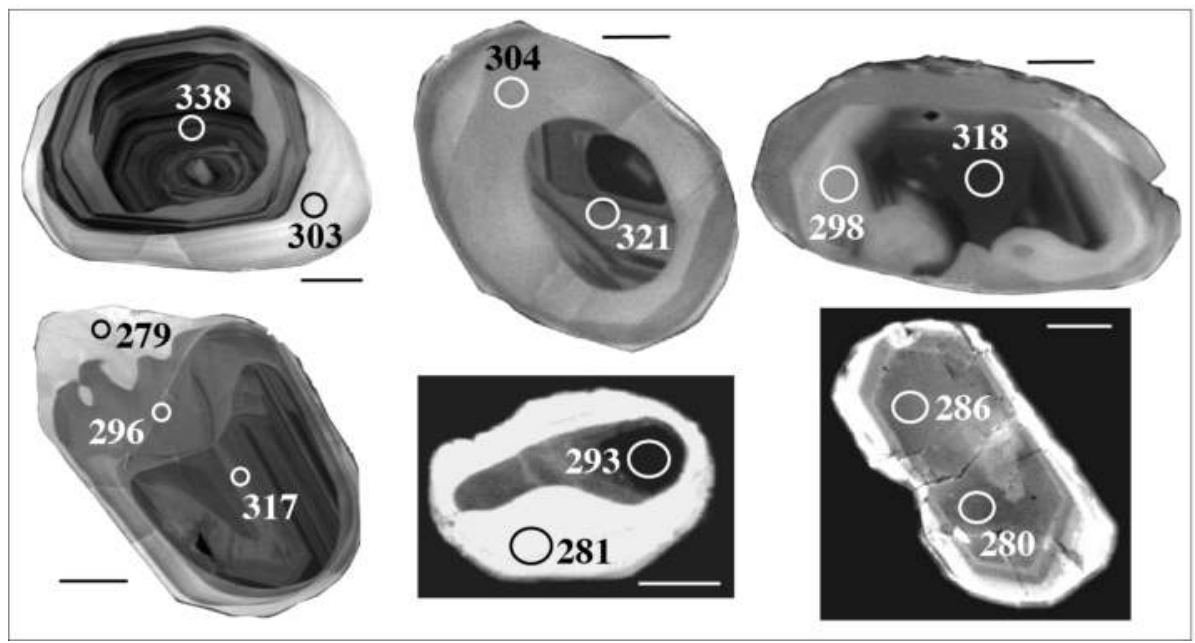

Figure 8. VPSED images of selected Variscan zircons. See the oscillatory zoning domains surrounded or invaded by lobate structurless grey or luminescent rims. Scale bar: $50 \mu \mathrm{m}$.

During the crustal thinning and decompression, emplacement of huge Late-Variscan calcalkaline granitoids occurred:1) between the upper and lower crustal portions of the Sila Unit (Fig. 4) at about $300 \mathrm{Ma}$ ago as showed by $\mathrm{Rb}-\mathrm{Sr}$ isotopic ages [52] and $\mathrm{U}-\mathrm{Pb}$ zircon ages in granodorities and tonalities of the Serre batholite [96], 2) in the Castagna Unit as showed by $\mathrm{U}-\mathrm{Pb}$ dating of zircons in a pegmatitic dike (sample GO82, Table 1, Fig. 9b) and 3) in CPU as showed by U-Pb zircon ages from peraluminous magmatites [19] (Table 1).

The geological evolution of the continental crust in Calabria was detailed utilizing the precious textures of zircons and the $\mathrm{U}-\mathrm{Pb}$ zircon data; the reconstructed scenario is confirmed by the comparison with similar metamorphic evolution of other lower crust fragments from the South European Variscides cropping out in the West Mediterranean areas [97-101]. 


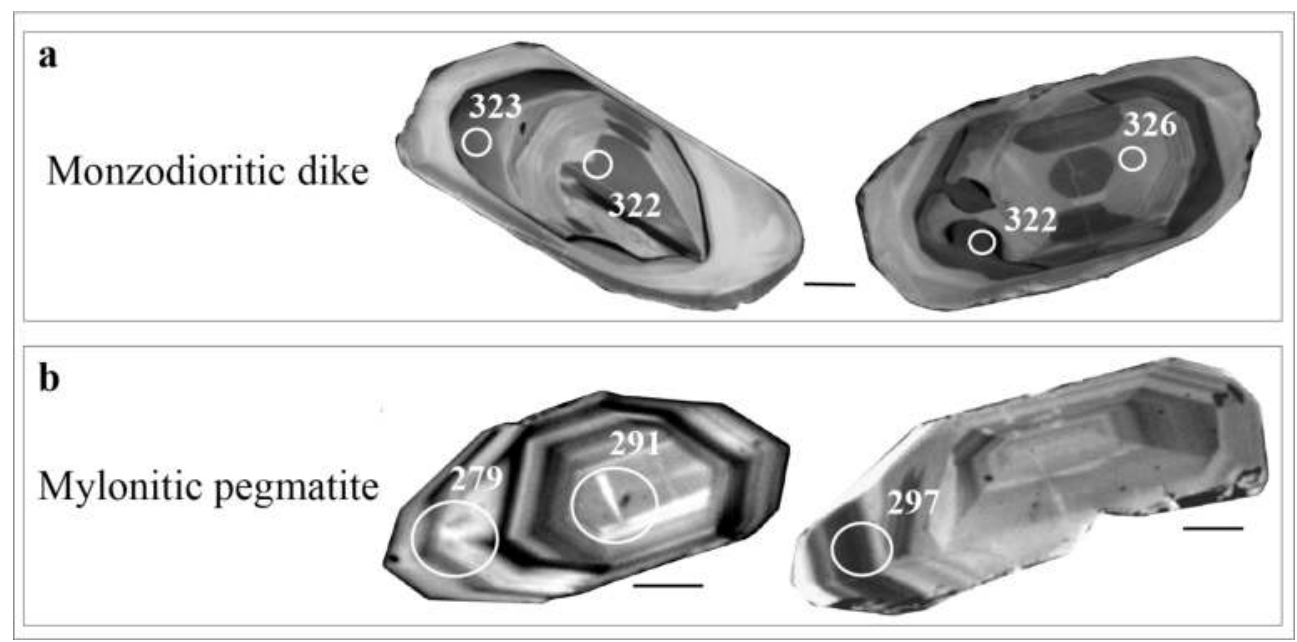

Figure 9. Magmatic zoning (VPSE images) in Variscan magmatites. Scale bar: $50 \mu \mathrm{m}$.

A limitation of the $\mathrm{U}-\mathrm{Pb}$ spot analyses on zircon is the spot size; in fact the augen gneisses interleaved with the migmatitic metasediments of the lower crust of the Serre (Calabria) show a thin recrystallized rim clearly shown by the cathodoluminescent images but undatable for the small size. Speculatively, these thin rims have been interpreted as formed during the Variscan metamorphism by [16], but their precise ages are not known.

\subsubsection{Post lower Permian events}

Few and scattered zircon ages comprised between 268 \pm 8 Ma and 231 \pm 5 Ma [72] (Table 1, Fig. 10) were measured in the granulites of the Sila Unit and in metamorphites and magmatites of the Castagna Unit. These ages have been interpreted as effect of a recrystallization event assisted by fluids [16,18,7]. A comparison with Variscan basements from Corsica [100] and Western Alps as the Ivrea zone [102,103] show similar cluster ages interpreted as precursor signals of the opening of the Tethys Ocean. An analogous interpretation can be adopted for the Calabria rock types associated to domains formed during the opening of Tethys Ocean. However, it can not be excluded that these ages in Calabria might be connected to opening of $\mathrm{U}-\mathrm{Pb}$ isotopic system of zircon due to Alpine tectonism [18], in fact the studied rocks belong to tectonic units stacked during the construction of Alpine chain and are affected by Alpine shear zones $[49,46]$. 


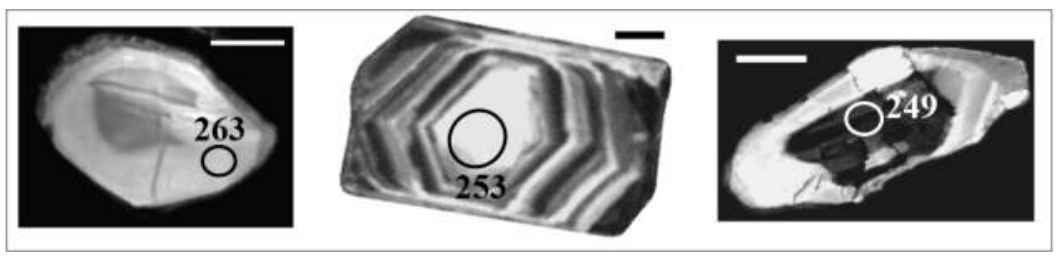

Scale bar: $50 \mu \mathrm{m}$

Figure 10. VPSED images of selected zircons showing post Lower-Permian ages.

\section{Conclusions}

The reconstruction of the pressure-temperature-time (P-T-t) evolution of crustal sections is fundamental to understanding many tectonic processes. This task, particulary difficult in the case of polymetamorphic rocks, requires the combination of metamorphic petrology and geochronology of different mineral phases that potentially can record more than one geological event. Zircon has been largely used for this role in high-grade terrains because its U-Pb system is able to retain the memory of polyphase evolution even at relatively high temperatures for its highly refractory nature, high closure temperature and slow $\mathrm{Pb}$ diffusion rate. Zircon is an ideal mineral for U-Pb dating of poly-metamorphic rocks [90,104-106,8,107-113]. In addition, the precise and accurate dating of the retrograde metamorphism is crucial for understanding the exhumation history of the ancient metamorphic basements. Obviously, spot U-Pb zircon data in magmatites formed under high temperature conditions, constrains the timing of magma emplacement and bring light on the geological context in which the magmatism explicated.

The case study presented in this paper shows as in situ zircon dating linked with determined $\mathrm{P}-\mathrm{T}$ conditions could constrain the evolution of the Calabria-Peloritani Terrane, a crucial fragment of Southern European Variscan Belt.

In the last ten years the advances in analytical capabilities have permitted in-situ investigation of complex zircon grains that allow us to reconstruct the geological history from Neoproterozoic-Cambrian to post Permian times in Southern Italy. In Fig.11 a histogram and a probability density curve of the U-Pb spot zircon ages collected in CPT are reported showing the large number of determinations in a wide time interval from Archean to Triassic ages.

The collected data are interpreted as suggestive of: (1) Neoproterozoic detrital input from cratonic areas of Gondwana testified by inherited zircons; (2) diachronic bimodal basic and acidic magmatism between 570 and $526 \mathrm{Ma}$, relative to an active tectonic margin setting; (3) rifting and opening of Ordovician-Silurian basins signed by consistent cluster ages around 450 Ma corresponding to acidic and intermediate volcanic activity (porphyroids and metaandesites in Peloritani Mountains); 4) Variscan granulite facies metamorphism and pervasive partial melting in deep crustal rocks of the Sila Unit; 5) precursor signals of the Tethys evolution showed by post Permian zircon domains. 


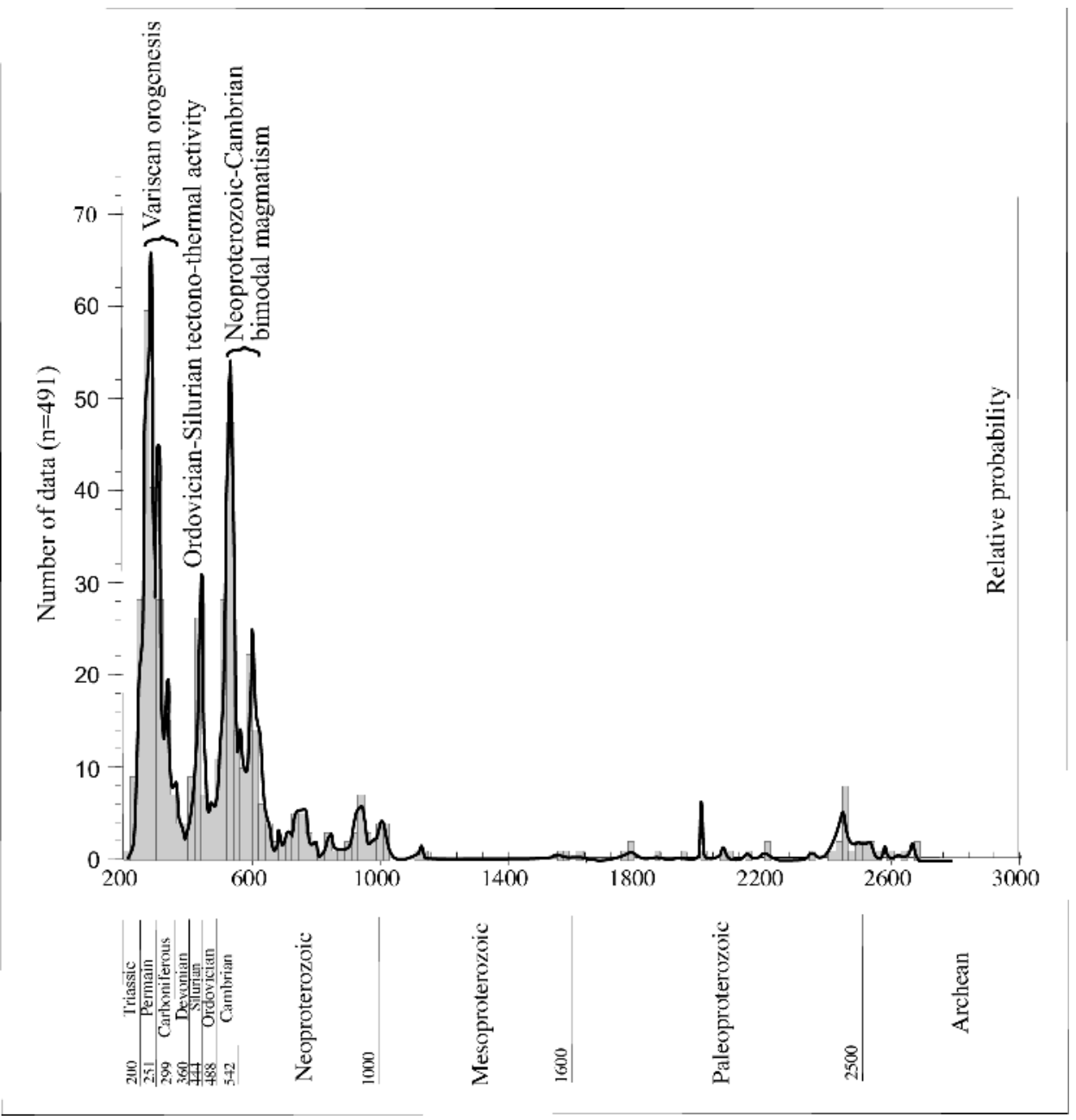

Figure 11. Histogram and probability density curve for U-Pb concordant data on zircon ( $n=491)$ from CPT (Tab.1). References: [7, 15-24].

\section{Author details}

Annamaria Fornelli*, Giuseppe Piccarreta and Francesca Micheletti

*Address all correspondence to: annamaria.fornelli@uniba.it

Dip. di Scienze della Terra e Geoambientali, Università degli Studi di Bari Aldo Moro, Italy 


\section{References}

[1] Scherer E E, Whitehouse M J and Münker C. Zircon as a Monitor of Crustal Growth. Elements 2007; 3(1) 19-24.

[2] Cocherie A and Robert M. Laser ablation coupled with ICP-MS applied to U-Pb zircon geochronology: A review of recent advances. Gondwana Research 2008; 14, 597608.

[3] Ru-Xiong L, Chang-Zhi W, Lian-Xing G, Zun-Zhong Z, Guo-Xiang C, Yao-Hui J. Zircon $\mathrm{U}-\mathrm{Pb}$ chronology and $\mathrm{Hf}$ isotope of the Xingxingxia granodiorite from the Central Tianshan zone (NW China): Implications for the tectonic evolution of the southern Altaids. Gondwana Research 2011; 20 582-593.

[4] Ireland TR and Williams IS., 2003. Considerations in zircon geochronology by SIMS. In: Hanchar JM and Hoskin PWO (ed.) Zircon, Reviews in Mineralogy \& Geochemistry; 2003. (53), 215-241.

[5] Kosler J and Sylvester PJ. Present trends and the future of zircon in geochronology: laser ablation ICPMS. In: Hanchar JM and Hoskin PWO (ed.) Zircon, Reviews in Mineralogy \& Geochemistry; 2003. (53), 243-275.

[6] Corfu F, Hanchar JM, Hoskin PWO, Kinny P. Atlas of zircon textures. In: Hanchar JM and Hoskin PWO (ed.) Zircon, Reviews in Mineralogy \& Geochemistry; 2003. (53), 468-500.

[7] Fornelli A, Langone A, Micheletti F, Piccarreta G. Time and duration of Variscan high-temperature metamorphic processes in the south European Variscides. Constraints from $\mathrm{U}-\mathrm{Pb}$ chronology and trace - element chemistry of zircon. Mineralogy and Petrology 2011; 103, 101-122.

[8] Rubatto D. Zircon trace element geochemistry: partitioning with garnet and the link between U-Pb ages and metamorphism. Chemical Geology 2002; 184,123-138.

[9] Moller A, O’Brien PJ, Kennedy A, Kroner A. Polyphase zircon in ultrahigh-temperature granulites (Rogaland, SW Norway): constraints for $\mathrm{Pb}$ diffusion in zircon. Journal of Metamorphic Geology 2002; 20, 727-740.

[10] $\mathrm{Wu} \mathrm{Y}$ and Zheng Y. Genesis of zircon and its constraints on interpretation of U-Pb age. Chinese Science Bulletin 2004; 49(15), 1554-1569.

[11] Harley S and Kelly NM. The impact of zircon - garnet REE distribution data on the interpretation of zircon $\mathrm{U}-\mathrm{Pb}$ ages in complex high - grade terrains: an example from the Rauer Islands, east Antarctica. Chemical Geology 2007; 241, 62-87.

[12] Nehring F, Foley SF, Hölttä P, Van Den Kerkhof. Internal differentiation of the Archean continental crust: fluid-controlled partial melting of granulites and TTG-amphibolite associations in central Finland. Journal of Petrology 2009; 50(1), 3-35. 
[13] Xia X, Sun M, Geng H, Sun Y, Wang Y, Zhao G. Quasi-simultaneous determination of $\mathrm{U}-\mathrm{Pb}$ and $\mathrm{Hf}$ isotope compositions of zircon by excimer laser-ablation multiplecollector ICPMS. Journal of Analitycal Atomic Spectrometry 2011; 26, 1868-1871.

[14] Zhou LG, Xia XQ, Zheng YF, Chen RX. Multistage growth of garnet in ultrahighpressure eclogite during continental collision in the Dabie orogen: constrained by trace elements and U-Pb ages. Lithos 2011; 127, 101-127.

[15] Trombetta A, Cirrincione R, Corfu F, Mazzoleni P, Pezzino A. Mid-Ordovician $\mathrm{U}^{\wedge} \mathrm{Pb}$ ages of porphyroids in the Peloritan Mountains (NE Sicily): paleogeographic implications for the evolution of the Alboran microplate. Journal of the Geological Society, London 2004; 161, 1-13.

[16] Micheletti F, Barbey P, Fornelli A, Piccarreta G, Deloule E. Latest Precambrian to Early Cambrian $\mathrm{U}-\mathrm{Pb}$ zircon ages of augen gneisses from Calabria (Italy), with inference to the Alboran microplate in the evolution of the peri-Gondwana terranes. International Journal of Earth Sciences 2007; 96(5) 843-860.

[17] Micheletti F, Fornelli A, Piccarreta G, Barbey P, Tiepolo M. The basement of Calabria (southern Italy) within the context of the Southern European Variscides: LA-ICPMS and SIMS U-Pb zircon study. Lithos 2008; 104, 1-11.

[18] Micheletti F, Fornelli A, Piccarreta G, Tiepolo M. U-Pb zircon data of Variscan metaigneous acidic rocks from an Alpine shear zone in Calabria (southern Italy). International Journal of Earth Sciences 2011; 100(1), 139-155.

[19] Fiannacca P, Williams IS, Cirrincione R, Pezzino A. Crustal Contributions to Late Hercynian Peraluminous Magmatism in the Southern Calabria Peloritani Orogen, Southern Italy: Petrogenetic Inferences and the Gondwana Connection. Journal of Petrology 2008; 49, 1897-1514.

[20] Langone A. Herynian low-pressure metamorphism: tectono-thgermal evolution of the Mandatoriccio complex (Sila Massif, Calabria). PhD thesis. Università di Bologna (Italy); 2008.

[21] Grande A. Evoluzione tettono-metamorfica delle metamorfiti affioranti a Palizzi Marina (Massiccio dell'Aspromonte, Calabria). PhD thesis. Università degli Studi di Bari Aldo Moro (Italy); 2009.

[22] Fornelli A, Langone A, Micheletti F, Pascazio A, Piccarreta G. The role of trace element partitioning between garnet, zircon and orthopyroxene on the interpretation of zircon U-Pb ages: an example from high-grade basement in Calabria (Southern Italy). International Journal of Earth Sciences 2014; 103(2), 487-507.

[23] Williams IS, Fiannacca P, Cirrincione R, Pezzino A. Peri-Gondwanian origin and early geodynamic history of NE Sicily: A zircon tale from the basement of the Peloritani Mountains. Gondwana Research 2012; 22, 855-865. 
[24] Muschitiello A. Geochimica, geochimica isotopica ed età U-Pb su zirconi dei metagabbri e delle metabasiti nella crosta profonda ercinica delle Serre (Calabria). Università degli Studi di Bari Aldo Moro (Italy); 2012.

[25] Griffin BJ, Joy DC, Michael JR. A Comparison of a Luminescence-Based VPSE and an Electron-Based GSED for SE and CL Imaging in Variable Pressure SEM with Conventional SE Imaging. Microscopy and Microanalysis 2010; 16(2), 624-625.

[26] Acquafredda P and Fiore S. La microscopia elettronica a scansione. In "Argille e minerali delle argille" 2005; (V), 143-188.

[27] Gerdes A. and Zeh A. Combined U-Pb and Hf isotope LA-(MC-)ICP-MS analyses of detrital zircons: Comparison with SHRIMP and new constraints for the provenance and age of an Armorican metasediment in Central Germany. Earth and Planetary Science Letters 2006; 249(1-2), 247-61.

[28] Horn I, Rudnick RL, Mc Donough WF. Precise elemental and isotope ratio determination by simultaneous solution nebulization and laser ablation-ICP-MS: application to U-Pb geochronology. Chemical Geology 2000; 164, 281-301.

[29] Tiepolo M. In situ Pb geochronology of zircon with laser ablation-inductively coupled plasma-sector field mass spectrometry. Chemical Geology 2003; 199, 159-177.

[30] Wiedenbeck M, Allé P, Corfu F, Griffin WL, Meier M, Oberli F, Von Quadt A, Roddick JC, Spiegel W. Three natural zircon standards for U-Th-Pb, Lu-Hf, trace elements and REE analyses. Geostandard Newletters 1995; 19, 1-23.

[31] Ketchum JWF, Jackson SE, Culshaw NG, Barr SM. Depositional and tectonic setting of the Paleoproterozoic Lower Aillik Group, Makkovik Province, Canada: evolution of a passive margin - foredeep sequence based on petrochemistry and U-Pb (TIMS and LAM-ICP-MS) geochronology. Precambrian Research 2001; 105, 331- 356.

[32] van Achterbergh E, Ryan CG, Jackson S, GriffinW. Data reduction software for LAICPMS. In: Sylvester P (ed.) Laser ablation ICPMS in the earth science. Mineralogy Association Canada 2001; 29, 239-24.

[33] Horstwood MSA, Foster GL, Parrish RR, Noble SR, Nowell GM. Common-Pb corrected in situ U-Pb accessory mineral geochronology by LA-MC-ICP-MS. Journal of Analytical Atomic Spectrometry 2003; 18, 837-846.

[34] Compston W, Williams IS, Meyer C. U-Pb geochronology of zircons from lunar breccia 73217 using a sensitive high mass-resolution ion microprobe. Journal of geofisical research: Solid Earth 1984; 89(S02), B525-B534.

[35] Stacey JS and Kramers JD. Approximation of terrestrial lead isotope evolution by a two-stage model. Earth and Planetary Science Letters 1975; 26, 207-221. 
[36] Deloule E, Alexandrov P, Cheilletz A, Laumonier B, Barbey P. In situ U/Pb zircon ages for Early Ordovician magmatism in the eastern Pyrenees, France: the Canigou orthogneisses. International Journal of Earth Sciences 2002; 91, 398-405.

[37] Williams I S and Claesson S. Isotopic evidence for the Precambrian provenance and Caledonian metamorphism of high grade paragneisses from the Seve Nappes, Scandinavian Caledonides: II. Ion microprobe zircon U-Th-Pb. Contributions to Mineralogy and Petrology 1987; 97, 205-217.

[38] Claoue.-Long JC, Compston W, Roberts J, Fanning CM. Two Carboniferous ages: a comparison of SHRIMP zircon dating with conventional zircon ages and 40Ar/39Ar analysis. In: Berggren WA, Kent DV, Aubrey MP, Hardenbol J. (ed.) Geochronology, Time Scales and Global Stratigraphic Correlation. Society of Economic Paleontologists and Mineralogists 1995, Special Publication 54, p3-21.

[39] Cumming GL and Richards JR. Ore lead isotope ratios in a continuously changing Earth. Earth and Planetary Science Letters 1975; 28, 155-171.

[40] Steiger RH and Jager E. Subcommission on geochronology: convention on the use of decay constants in geo-and cosmochronology. Earth and Planetary Science Letters 1977; 36, 359-362.

[41] Ludwig KR. User's Manual for A Geochronological Toolkit for Microsoft Excel. Berkeley Geochronology Center, Spec Publ No. 4; 2003.

[42] Bonardi G, Cavazza W, Perrone V, Rossi S. Calabria-Peloritani terrane and northern Ionian Sea. In: Vai GB, Martini IP (ed.) Anatomy of an Orogen: the Apennines and Adjacent Mediterranean Basins. Kluwer Academic Publishers; 2001. p 287-306.

[43] Festa V, Messina A, Paglionico A, Piccarreta G, Rottura A. Pre-Triassic history recorded in the Calabria-Peloritani segment of the Alpine chain, southern Italy. An overview. Spec Iss 2: A showcase of the Italian research in metamorphic petrology. Periodico di Mineralogia 2004; 73, 57-71.

[44] Acquafredda P, Lorenzoni S, Zanettin-Lorenzoni E. La sequenza Paleozoica dell'Unità di Bocchigliero (Sila, Calabria). Rendiconti Società Geologica Italiana 1988; 11, 5-22.

[45] Acquafredda P, Barbieri M, Lorenzoni S, Zanettin-Lorenzoni E. The age of volcanism and metamorphism of the Bocchigliero Paleozoic sequence (Sila - southern Italy). Rendiconti Accademia dei Lincei 1991; 9, 145-156.

[46] Langone A, Godard G, Prosser G, Caggianelli A, Rottura A, Tiepolo M. P-T-t path of the Variscan low-pressure rocks from the Mandatoriccio complex (Sila Massif, Calabria, Italy): new insights for crustal evolution. Journal of Metamorphic Geology 2010; 28,137-162.

[47] Lorenzoni S and Zanettin-Lorenzoni E. Note illustrative della carta geologica della Sila alla scala 1:200.000. Memorie della Società Geologica Italiana 1983; 36, 317-342. 
[48] Borghi A, Colonna V. Compagnoni R. Structural and metamorphic evolution of the Bocchigliero and the Mandatoriccio Complex in the Sila nappe (Calabrian-Peloritan Arc, Southern Italy). IGCP n²76, Newsletters 1992; 5, 321-334.

[49] Colonna V and Piccarreta G. Contributo alla conoscenza dell'Unità di Castagna in Sila Piccola: rapporti tra micascisti, paragneiss e gneiss occhiadini. Bollettino Società Geologica Italiana 1976; 95, 39-48.

[50] Paglionico A and Piccarreta G. Le Unità del Fiume Pomo e di Castagna nelle Serre Settentrionali (Calabria). Bollettino Società Geologica Italiana 1976; 95, $27-37$.

[51] Caggianelli A, Prosser G, Del Moro A. Cooling and exhumation history of deep-seated and shallow level, late Hercynian granitoids from Calabria. Geological Journal 2000; 35, 33-42.

[52] Schenk $\mathrm{V}$. U-Pb and $\mathrm{Rb}-\mathrm{Sr}$ radiometric dates and their correlation with metamorphic events in the granulite-facies basement of the Serre, Southern Calabria (Italy). Contribution to Mineralogy and Petrology 1980; 73,23-38.

[53] Fiannacca P, Williams IS, Cirrincione R, Pezzino A. The augen gneisses of the Peloritani Mountains (NE Sicily): Granitoid magma production during rapid evolution of the northern Gondwana margin at the end of the Precambrian. Gondwana Research 2013; 23(2), 782-796.

[54] D’Amico C, Rottura A, Maccarrone E, Puglisi G. Peraluminous granitic suite of Calabria-Peloritani arc (Southern Italy). Rendiconti Società Italiana Mineralogia e Petrologia 1982; 38, 35-52.

[55] Rottura A, Bargossi GM, Caironi V, Del Moro A, Maccarrone E, Macera P, Paglionico A, Petrini R, Piccareta G, Poli G. Petrogenesis of contrasting Hercynian granitoids from the Calabrian Arc, Southern Italy. Lithos 1990; 24, 97-119.

[56] Rottura A, Caggianelli A, Campana R, Del Moro A. Petrogenesis of Hercynian peraluminous granites from the Calabrian Arc, Italy. European Journal of Mineralogy 1993; 5, 737-754.

[57] Fiannacca P, Brotzu P, Cirrincione R, Mazzoleni P, Pezzino A. Alkali metasomatism as a process for trondhjemite genesis: evidence from Aspromonte Unit, north-eastern Peloritani, Sicilyan Mineralogy and Petrology, 2005(a); 84, 19-45.

[58] Ortolano G, Cirrincione R, Pezzino A. P-T evolution of alpine metamorphism in the southern Aspromonte Massif (Calabria-Italy). Schweizer Mineralogische und Petrographische Mitteilungen 2005; 85(1), 31-56.

[59] Cirrincione R, Fazio E, Fiannacca P, Ortolano G, Pezzino A, Punturo R. Petrological and microstructural constraints for orogenetic exhumation modelling of HP rocks: The example of southern Calabria Peloritani Orogen (Western Mediterranean), in GeoMod 2008, Third International Geomodelling Conference, Firenze, 22-24 September 2008. Bollettino Geofisica Teorica e Applicata 2008; 49(2), 141-146. 
[60] Schenk V and Todt W. Age of formation of the southern Calabrian crust. Terra Abstracts $1989 ; 1,350$.

[61] Schenk V. The exposed crustal cross section of southern Calabria, Italy: structure and evolution of a segment of Hercynian crust. In: Salisbury MH, Fountain DM (ed.) Exposed Cross-sections of the Continental Crust. Kluwer Academic Publisher, Netherlands; 1990. p.21-42.

[62] Cahen L, Snelling NJ, Delhal J, Vail JR. The Geochronology and Evolution of Africa. Clarendon Press, Oxford; 1984.

[63] Mallard LD, Rogers JJW. Relationship of Avalonian and Cadomian terranes to Grenville and Pan-African events. Journal of Geodynamics 1997; 23,197-221.

[64] [64] Zeck HP and Williams IS. Inherited and Magmatic Zircon from Neogene Hoyazo Cordierite Dacite, SE Spain-Anatectic Source Rock Provenance and Magmatic Evolution. Journal of Petrology 2002; 43 (6), 1089-1104

[65] [65] Samson SD, D'Lemos RS, Miller BV, Hamilton MA. Neoproterozoic paleogeography of the Cadomia and Avalon terranes: constraints from detrital zircon $\mathrm{U}-\mathrm{Pb}$ ages. Journal of Geological Society of London 2005;162,65-71.

[66] [66] Murphy J B, Gutierrez-Alonso G, Nance R D, Fernandez-Suarez J, Keppie J D, Quesada C, Strachan R A, Dostal J. Origin of the Rheic Ocean: Rifting along a Neoproterozoic suture? Geological Society of America 2006; 34(5), 325-328.

[67] [67] Stampfli G.M., von Raumer J. and Wilhem C. The distribution of Gondwana-derived terranes in the Early Paleozoic. J.C. Gutiérrez-Marco, I. Rábano and D. GarcíaBellido (ed.), Ordovician of the World; 2011. p.567-574. ISBN 978-84-7840-857-3.

[68] [68] von Raumer JF, Bussy F, Schaltegger U, Schulz B, Stampfli GM. Pre-Mesozoic Alpine basements - Their place in the European Paleozoic framework. GSA Bulletin 2013; 125 (1-2), 89-108.

[69] [69] Hanchar JM, Miller CF. Zircon zonation patterns as revealed by cathodoluminescence and backscattered electron images: implications for interpretation of complex crustal histories. Chemical Geology 1993; 110, 1-13.

[70] [70] Duchene S, Fornelli A, Micheletti F, Piccarreta G. Sm-Nd chronology of porphyroblastic garnets from granulite facies metabasic rocks in Calabria (Southern Italy): inferences for preserved isotopic memory and resetting. Mineralogy and Petrology 2013; 107(4), 539-551.

[71] Neubauer F. Evolution of late Neoproterozoic to early Paleozoic tectonic elements in Central and Southeast European Alpine mountain belts: review and synthesis. Tectonophysics 2002; 352, 87-103.

[72] Fornelli A, Langone A, Micheletti F, Piccarreta G. Application of U-Pb dating and chemistry of zircon in the continental crust of Calabria (Southern Italy). In: Van Dijk 
G, Van den Berg V (ed.) Zircon and Olivine: Characteristics, Types and Uses; 2012. ebook ISBN: 978-1-62100-990-0

[73] Rubatto D and Hermann J. Experimental zircon/melt and zircon/ garnet trace element partitioning and implications for the geochronology of crustal rocks. Chemical Geology 2007; 241, 62-87.

[74] Xia XQ, Zheng YF, Yuan H, Wu FY. Contrasting Lu-Hf and U-Th-Pb isotope systematics between metamorphic growth and recrystallization of zircon from eclogitefacies metagranites in the Dabie orogen, China. Lithos 2009; 112(3-4),477-496.

[75] Fornelli A, Micheletti F, Piccarreta G. The Neoproterozoic-Early Cambrian felsic magmatism in Calabria (Italy): inferences as to the origin and geodynamic setting. Periodico di Mineralogia 2007; SPECIAL ISSUE 76, 99-112.

[76] Fiannacca P, Williams I, Cirrincione R, Pezzino A. Post-collisional granitoid magmatism in the Calabria-Peloritani Terrane during the final stages of north Gondwana assembly. Geoitalia 2011, 19-23 September 2011, Torino, Italy. Epitome 04.0632.

[77] Thomas RJ, Chevallier LP, Gresse PG, Harmer RE, Eglington BM, Armstrong RA, de Beer CH, Martini JEJ, de Kock GS, Macey PH, Ingram BA. Precambrian evolution of the Sirwa Window, Anti-Atlas Orogen, Morocco. Precambrian Research 2002; 118, 157.

[78] Walsh GJ, Aleinikoff J, Benziane F, Yazidi A, Armstrong TR. U-Pb zircon geochronology of the Palaeoproterozoic Tagragra de Tata inlier and its Neoproterozoic cover, western Anti-Atlas, Morocco. Precambrian Research 2002; 117, 1-20.

[79] Acef K, Liégeois JP, Ouabadi A, Latouche L. The Anfeg post-collisional Pan-African high-K calc-alkaline batholith (Central Hoggar, Algeria), result of the LATEA microcontinent metacratonisation. Journal of African Earth Sciences 2003; 37, 295-311.

[80] Azzouni-Sekkal A, Liégeois JP, Bechiri-Benmerzoug F, Belaidi-Zinet S, Bonin B. The "Taourirt" magmatic province, a marker of the closing stage of the Pan-African orogeny in the Tuareg Shield: review of available data and Sr-Nd isotope evidence. Journal of African Earth Sciences 2003; 37, 31-350.

[81] Lahondère D, Thiéblemont D, Goujou JC, Le Métour J, Barbey P, Bronner G, Deschamps M, Cocherie A, Guerrot C, Marchand J. Evolution archéenne à paléoprotérozoïque de la Dorsale de Rgueïbat (Nord de la Mauritanie). 20th Coll Afr Geol, Orléans, 2004. Abstract, p 251.

[82] Stedra V, Kachlik V, Kryza, R. Coronitic metagabbros of the Mariánské Lázně Complex and Teplá Crystalline Unit: inferences for the tectonometamorphic evolution of the western margin of the Teplá-Barrandian Unit, Bohemian Massif. Geological Society, London, Special Publications 2002; 201, 217-236.

[83] Gasquet D, Levresse G, Cheilletz A, Azizi-Samir MR, Mouttaqi A. Contribution to a geodynamic resconstruction of the Anti-Atlas (Morocco) during Pan-African times 
with the emphasis on inversion tectonics and metallogenic activity at the Precambrian-Cambrian transition. Precambrian Research 2005; 140,157-182.

[84] Vavra G, Gebauer D, Schmid R, Compton W. Multiple zircon growth and recrystallization during polyphase Late Carboniferous to Triassic metamorphism in granulite of Ivrea Zone (Southern Alps): an ion microprobe (SHRIMP) study. Contrib Mineral Petrol 1996; 122, 337-358.

[85] Vavra G, Schmid R, Gebauer D. Internal morphology, habit and U-Th-Pb microanalysis of amphibolite-to-granulite facies zircons: geochronology of the Ivrea Zone (Southern Alps). Contribution to Mineralogy and Petrology 1999; 134, 380-404.

[86] Schenk V. P-T-t path of the lower crust in the Hercynian fold belt of southern Calabria. In: Daly JS, Cliff RA, Yardley BWD (ed.) Evolution of metamorphic belts. Geological Society Special Publication 1989. 43, 337-342.

[87] Faure, M. Microtéctonique et charriage Est-Ouest des nappes alpines profondes de Sila (Calabre, Italie méridionale). Revue de Géologie Dynamique et Géographie Physique 1980; 22(2), 135-146.

[88] Amodio Morelli L, Bonardi G, Colonna V, Dietrich D, Giunta G, Ippolito F, Liguori V, Lorenzoni S, Paglionico A, Perrone V, Piccarreta G, Russo M, Scandone P, Zanettin Lorenzoni E, Zuppetta A. L'arco Calabro-Peloritano nell'orogene AppenninicoMaghrebide. Memorie Società Geologica Italiana 1976; 17, 1-60.

[89] Del Moro A, Fornelli A, Piccarreta G. Tectonothermal history of the Hercynian continental crust of the Serre (southern Calabria, Italy) monitored by $\mathrm{Rb} / \mathrm{Sr}$ biotite resetting. Terra Nova 2000; 12, 239-244.

[90] Lee JKW, Williams IS, Ellis DJ. Determination of $\mathrm{Pb}, \mathrm{U}$ and $\mathrm{Pb}$ diffusion rates in zircon. Abstract, GAC/MAC Annual Meeting, Ottawa 1997 A87.

[91] Cherniak DJ, Hanchar JM, Watson EB. Rare-earth diffusion in zircon. Chemical Geology 1997; 134, 289-301.

[92] Cherniak DJ and Watson EB. Pb diffusion in zircon. Chemical Geology 2000; 172, 5-24.

[93] Angì G, Cirrincione R, Fazio E, Fiannacca P, Ortolano G, Pezzino A. Metamorphic evolution of preserved Variscan upper crust in the Alpine Calabria-Peloritani Orogen (southern Italy): structural and petrological constraints from the Serre Massif metapelites. Lithos 2010; 115, 237-262.

[94] Geisler T, Schaltegger U, Tomaschek F. Re-equilibration of zircon in aqueous fluids and melts. Elements 2007; 3(1), 43-50.

[95] Fornelli A, Pascazio A, Piccarreta G. Diachronic and different metamorphic evolution in the fossil Variscan lower crust of Calabria. International Journal of Earth Sciences 2012(b); 101(5),1191-1207. 
[96] Caggianelli A and Prosser G. Modelling the thermal perturbation of the continental crust after intraplating of thick granitoid sheets: a comparison with the crustal sections in Calabria (Italy). Geological Magazine 2002; 139(6), 699-706.

[97] Handy MR and Zingg A. The tectonic and rheological evolution of an attenuated cross section of the continental crust: Ivrea crustal section, southern Alps, northwestern Italy and southern Switzerland. Geological Society of America Bulletin 1991; 103, 236-253.

[98] Gardien V, Lardeaux JM, Ledru P, Allemand P, Guillot S. Metamorphism during late orogenic extension: insights from the French Variscan belt. Bulletin Société Géologique France 1997; 168, 271-286.

[99] Lardeaux J, Ledru P, Daniel I, Duchene S. The Variscan French Massif Central-a new addition to the ultra-high pressure metamorphic 'club': exhumation processes and geodynamic consequences. Tectonophysics 2001; 332, 143-167.

[100] Rossi P, Cocheri A, Fanning CM, Deloule E. Variscan to eo-Alpine events recorded in European lower-crust zircons sampled from the French Massif Central and Corsica, France. Lithos 2006; 87,235-260.

[101] Giacomini F, Bomparola RM, Grezzo C, Guldbransen H. The geodynamic evolution of the Southern European Variscides: constraints from the $\mathrm{U} / \mathrm{Pb}$ geochronology and geochemistry of the Palaeozoic magmatic-sedimentary sequences of Sardinia (Italy). Contribution to Mineralogy and Petrology 2006; 152,19-42.

[102] Lu M, Hofmann AW, Mazzucchelli M, Rivalenti G. The maficultramafic complex near Finero (Ivrea-Verbano Zone). II. Geochronology and isotope geochemistry. Chemical Geology 1997; 140, 223-235.

[103] Peressini G, Quick JE, Sinigoi S, Hofmann AW, Fanning M. Duration of a large mafic intrusion and heat transfer in the lower crust: a SHRIMP U-Pb zircon study in the Ivrea-Verbano Zone (Western Alps, Italy). Journal of Petrology 2007; 48, 1185-1218.

[104] Schaltegger U and Gebauer D. Pre-Alpine geochronology of the Central, Western and Southern Alps. Schweiz Mineral Petrogr Mitteilungen 1999; 79, $79-87$.

[105] Katayama I, Maruyama S, Parkinson CD, Terada K, Sano Y. Ion micro-probe U-Pb zircon geochronology of peak and retrograde stages of ultrahigh-pressure metamorphic rocks from the Kokchetav massif, northern Kazakhstan. Earth and Planetary Science Letters 2001; 188(1-2), 185-198.

[106] Hermann J, Rubatto D, Korsakov A, Shatsky VS. Multiple zircon growth during fast exhumation of diamondiferous, deeply subducted continental crust (Kokchetav Massif, Kazakhstan). Contributions to Mineralogy and Petrology 2001; 141(1), 66-82.

[107] Moller A, O’Brien PJ, Kennedy A, Kroner A. Polyphase zircon in ultrahigh-temperature granulites (Rogaland, SW Norway): constraints for $\mathrm{Pb}$ diffusion in zircon. Journal of Metamorphic Geology 2002; 20, 727-740. 
[108] $\mathrm{Wu} \mathrm{Y}$ and Zheng Y. Genesis of zircon and its constraints on interpretation of U-Pb age. Chinese Science Bulletin 2004; 49, 1554-1569.

[109] Liati A. Identification of repeated Alpine (ultra) high-pressure metamorphic events by U-Pb SHRIMP geochronology and REE geochemistry of zircon: the Rhodope zone of Northern Greece. Contributions to Mineralogy and Petrology 2005; 150, 608-630.

[110] Liu Y, Gao S, Hu Z, Gao C, Zong K, Wang D. Continental and oceanic crust recycling-induced melt-peridotite interactions in the Trans-North China Orogen: $\mathrm{U}-\mathrm{Pb}$ dating, Hf isotopes and trace elements in zircons from mantle xenoliths. Journal of Petrology 2010; 51(1-2), 537-571.

[111] McClelland WC, Power SE, Gilotti JA, Mazdab FK, Wopenka B. U-Pb SHRIMP geochronology and trace-element geochemistry of coesite-bearing zircons, North-East Greenland Caledonides. Geological Society of America, Special Paper 403, Ultrahighpressure Metamorphism: Deep Continental Subduction, 2006.

[112] Mcclelland WC, Gilotti JA, Mazdab FK, Wooden JL. Trace-element record in zircons during exhumation from UHP conditions, North-East Greenland Caledonides. European Journal of Mineralogy 2009; 21, 1135-1148.

[113] Chen RX, Zheng YF, Xie L. Metamorphic growth and recrystallization of zircon: distinction by simultaneous in situ analyses of trace elements, U-Th-Pb and Lu-Hf isotopes in zircons from eclogite-facies rocks in the Sulu orogen. Lithos 2010; 114, 132154. 
